\title{
Summary of Northeast Asia geodynamics and tectonics*
}

\author{
L. M. Parfenov ${ }^{1, \dagger}$, G. Badarch ${ }^{2}$, N. A. Berzin ${ }^{3}$, A. I. Khanchuk ${ }^{4}$, M. I. Kuzmin ${ }^{5}$, W. J. Nokleberg ${ }^{6}$, A. V. Prokopiev ${ }^{1}$, \\ M. Ogasawara ${ }^{7}$, and H. Yan $^{8}$ \\ ${ }^{1}$ Russian Academy of Sciences, Yakutsk, Russia \\ ${ }^{2}$ Mongolian Academy of Sciences, Ulaanbaatar, Mongolia \\ ${ }^{3}$ Russian Academy of Sciences, Novosibirsk, Russia \\ ${ }^{4}$ Russian Academy of Sciences, Vladivostok, Russia \\ ${ }^{5}$ Russian Academy of Sciences, Irkutsk, Russia \\ ${ }^{6}$ US Geological Survey, Menlo Park, USA \\ ${ }^{7}$ Geological Survey of Japan/AIST, Tsukuba, Japan \\ ${ }^{8}$ Jilin University, Changchun, China \\ $\dagger$ deceased
}

*Prepared in memory of Leonid M. Parfenov, the leader of the geodynamics map team for the International collaborative project on NE Asia tectonics and metallogenesis.

\begin{abstract}
The compilation, synthesis, description, and interpretation of regional geology and tectonics of major regions, such as Northeast Asia (Eastern Russia, Mongolia, Northern China, South Korea, and Japan) and the Circum-North Pacific (the Russian Far East, Alaska, and Canadian Cordillera), requires a complex methodology that includes: (1) definitions of key terms; (2) compilation of a regional geodynamics map that can be constructed according to modern tectonic concepts and definitions; and (3) formulation of a comprehensive tectonic model. This article presents a summary of the regional dynamics and tectonics of Northeast Asia as developed for a new summary geodynamics map of the region. This article also describes how a high-quality summary geodynamics map and companion tectonic analysis substantially aids in the understanding of the origin of major rock units, major structures, and contained mineral and fuel resources, and provides important guidelines for new research.
\end{abstract}

\section{Introduction}

This article presents an overview of the regional geodynamics and tectonics of Northeast Asia as presented in a new summary geodynamics map of the region, and also provides a general introduction for readers who are unfamiliar with Northeast Asia. For this analysis, the region of



Correspondence to: A. V. Prokopiev (prokopiev@diamond.ysn.ru)
Northeast Asia project area consists of Eastern Russia (Eastern Siberia and the Russian Far East), Mongolia, Northern China, the Korean Peninsula, Japan, and adjacent offshore areas (Fig. 1).

The summary of regional geodynamics and tectonics in this article is based upon publications of a major international collaborative study of the metallogenesis and tectonics of Northeast Asia and of the Circum-North Pacific, which were led by W. J. Nokleberg of the the US Geological Survey. Two broad types of publications have been produced by this collaboration. One type is a series of regional geologic, mineral deposit, and metallogenic belt maps and companion descriptions for the region (Greninger et al., 1999; Obolenskiy et al., 2003a, b, 2004; Parfenov et al., 2003, 2004a, b; Nokleberg et al., 1994, 1997a, b, c, 1998, 2004; Rodionov et al., 2004; and Naumova et al., 2006). The other type is a suite of metallogenic and tectonic analyses of these same regions (Nokleberg et al., 2000, 2005; Rodionov et al., 2004).

\section{Definitions, geologic time scale, and tectonic environments}

In order to illustrate the regional geology of a large region most clearly in a page-size format, Fig. 2 utilizes the concept of tectonic collages (see definition, Table 1). This definition of tectonic collage enables: (1) a readily-understood conceptual framework for understanding the geology and tectonics of large regions; (2) the depiction at small scales of major geologic units and structures that formed in a single tectonic

Published by Copernicus Publications on behalf of the European Geosciences Union. 


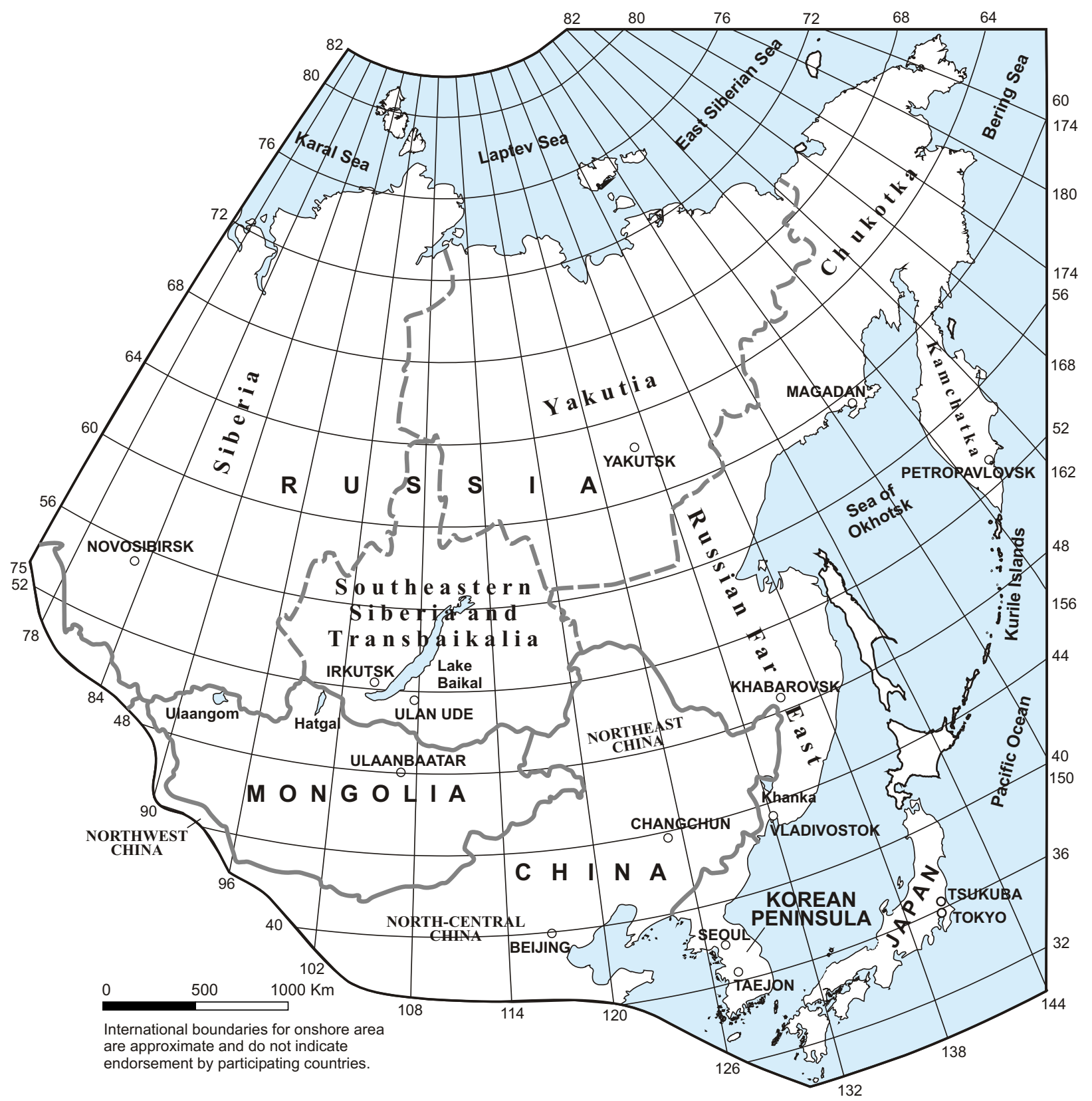

Fig. 1. Regional summary geographic map for Northeast Asia showing major regions and countries.

event; and (3) the understanding of the origins of major mineral and hydrocarbon deposits related to the formations and modification of tectonic collages.

Definitions of other key terms for the analysis of regional geology and tectonics are provided in Table 1. These definitions are adapted from Howell et al. (1985), Jones et al. (1983), and Nokleberg et al. (2000, 2005). Geologic time scale units are according to the IUGS Global Stratigraphic Chart (Remane, 1998). For this study and in some of the cited publications, the term Riphean is used for the Mesoproterozoic to Middle Neoproterozoic (1600 to $650 \mathrm{Ma}$ ), and the term Vendian is used for Neoproterozoic III (650 to $540 \mathrm{Ma})$.
For a modern geologic analysis, the classification into tectonic environments is essential for determining the geologic origins of major units and contained mineral and hydrocarbon resources. This permits the interpretations of origin of both host rocks and associated resources. For the tectonic analyses of Northeast Asia and the Circum-North Pacific (Nokleberg et al., 1997b, c, 2000, 2005; Scotese et al., 2001; Obolenskiy et al., 2003; Parfenov et al., 2003, $2004 \mathrm{a}, \mathrm{b}$ ), the major geologic units (terranes, overlap assemblages, plates), mineral deposits, mineral deposit types, and metallogenic belts, are classified into the following tectonic environments (Table 1): (1) cratonal and craton margin; 


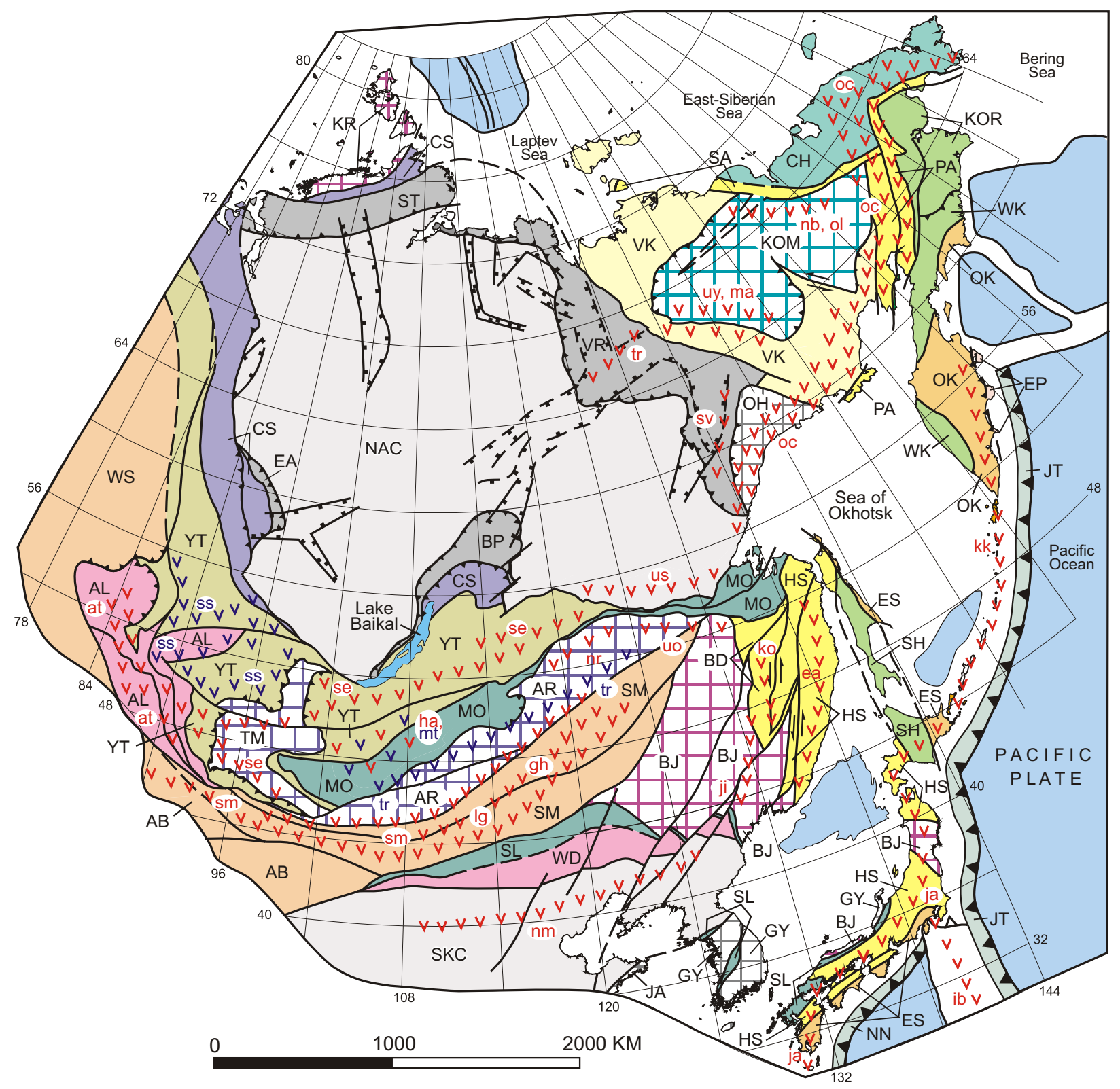

Symbols, Faults, and Contacts

(a)

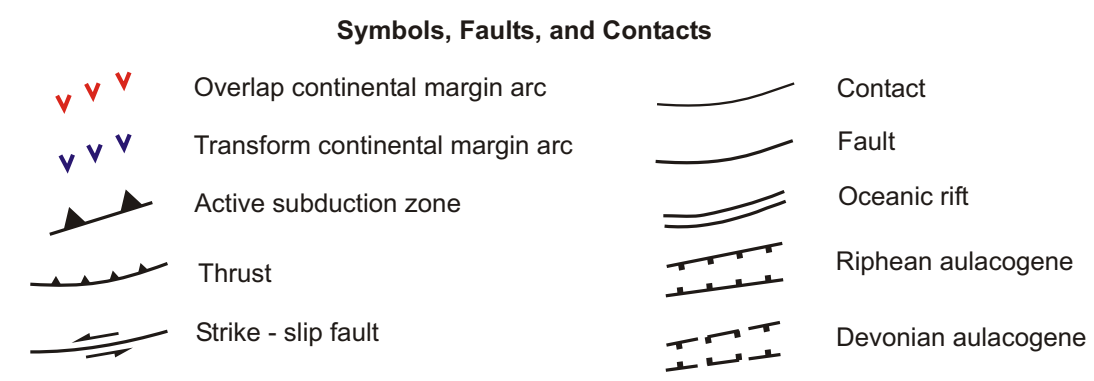

Fig. 2a. Northeast Asia summary geodynamics map. Map is derived from: (1) a generalized Northeast Asia geodynamics map at 10 million scale (Parfenov et al., 2004); (2) a more detailed Northeast Asia geodynamics map at 5 million scale (Parfenov et al., 2003); and (3) the western part of a Circum-North Pacific tectono-stratigraphic terrane map at 10 million scale (Nokleberg et al., 1997). Map shows locations major geologic and tectonic units including cratons, craton margins; cratonal terranes and superterranes; tectonic collages; overlap and transform continental-margin arcs; island arcs, and sea and ocean units. (a) Map. (b) Explanation. Refer to Appendix for descriptions of map units. 


\section{EXPLANATION}

\section{Cratons and Craton Margins}

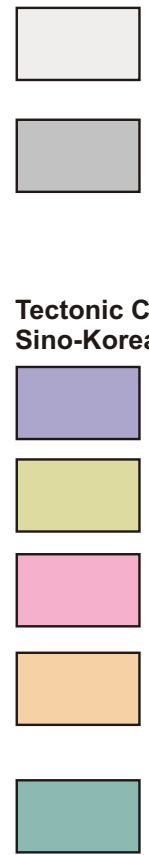

NAC - North Asian Craton (Archean and Proterozoic);SKC - Sino-Korean Craton (Archean and Proterozoic)

Craton Margin: BP - Baikal-Patom (Riphean to Cambrian and older basement; EA - East Angara (Riphean and older basement; ST - South Taimyr (Ordovician to Jurassic); VR - Verkhoyansk (Devonian to Jurassic).

Tectonic Collages Between North Asian and Sino-Korean Cratons (older to younger)

CS - Circum-Siberia (Proterozoic)

YT - Yenisey-Transbaikal (Vendian to Early Ordovician)

AL - Altay (Vendian to Ordovician) WD - Wundurmiao (Riphean to Ordovician)

$A B$ - Atasbogd (Ordovician through Permian); SM - South Mongolia-Khingan (Ordovician to Carboniferous); WS - West Siberian (Ordovician to Carboniferous)

MO - Mongol-Ohkotsk (Devonian to Late Jurassic); SL - Solon (Carboniferous to Permian)

Tectonic Collages Along Northern and Eastern Margins of North Asian and Sino-Korean Cratons (older to younger)

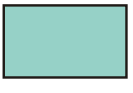

$\mathrm{CH}$ - Chukotka (Paleozoic to Triassic)

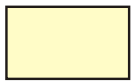

VK - Verkhoyansk-Kolyma Paleozoic to Early Jurassic)

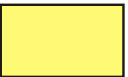

BD - Badzhal (Triassic to Early Cretaceous); PA - Penzhina-Anadyr (Late Jurassic to Cretaceous); HS - Honshu-Sikhote-Alin (Jurassic to Early Cretaceous); SA - South Anyui (Permian to Jurassic);

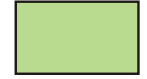

KOR - Koryak (Late Jurassic to Paleocene $\mathrm{SH}$ - Sakhalin-Hokkaido (Cretaceous); WK - West Kamchatka (Mid-Cretaceous to Early Tertiary)

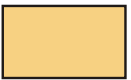

ES - East Sakhalin (Late Cretaceous to Early Tertiary); OK - Olyutorka-Kamchatka (Late Cretaceous to Paleocene)

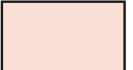

EP - East Kamchatka Peninsular (Mainly Paleocene)

\section{Active Subduction Zones}

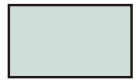

JT- Japan Trench (including Kuril-Kamchatka trench) (Miocene to Present); NN - Nankai (Miocene to Present)

(b)

Fig. 2b. Continued

\section{Cratonal Terranes and Superterranes}

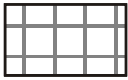

Cratonal Terranes (Archean and Proterozoic): GY - Gyeonggi-Yeongnam $\mathrm{JA}$ - Jiaonan; $\mathrm{OH}$ - Okhotsk

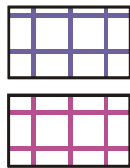

Late Proterozoic to Cambrian Supterterranes; AR - Argun-Idermeg; TM - Tuva-Mongolia

Archean to Permian Superterranes:

BJ - Bureya-Jiamusi; KR - Kara

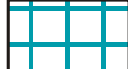

Jurassic Superterrane:

KOM - Kolyma-Omolon (Archean to Jurassic)

Sea and Ocean Units



Surficial units

Oceanic crust

\section{Overlap Continental Margin Arcs and Granite Belts}

at - Altay arc (Devonian and early Carboniferous, 381-290 Ma))

ea - East Sikhote-Alin arc (Late Cretaceous to early

Tertiary, 96-65 to Ma)

gh - Gobi-Khankaisk-Daxing'anling arc (Permian, 295-250 Ma)

lg - Lugyngol arc (Permian, 295-250 Ma)

ha - Hangay arc (Late Carboniferous to Early Permian, 320-272 Ma)

ji - Jihei arc (Permian, 295-250 Ma)

ko - Khingan-Okhotsk arc (Early and mid-Cretaceous)

ma Main granite belt (Late Jurassic, 144-134 Ma)

$\mathrm{nb}$ - Northern granite belt (Early Cretaceous, 138-120 Ma)

$\mathrm{nm}$ - North Margin (Late Carboniferous to Permian, 320-272 Ma)

$\mathrm{nr}$ - Norovlin arc (Devonian, 410-255 Ma)

oc - Okhotsk-Chukotka arc (Late Cretaceous to early Tertiary, 96-53 Ma)

ol - Oloy arc (Late Jurassic, 154-135 Ma)

se - Selenga arc (Permian to Jurassic, 295-135 Ma)

sm - South Mongolian arc (Middle Carboniferous through Triassic , 320-203 $\mathrm{Ma}$ )

sv - South Verkhoyansk granite belt (Late Jurassic to mid-Cretaceous, 157$93 \mathrm{Ma}$ )

tr - Transverse granite belt (Early Cretaceous, 134-124 Ma)

us - Uda-Murgal and Stanovoy arc (Jurassic to Early Cretaceous, 203-96 Ma)

uy - Uyandina-Yasachnaya arc (Late Jurassic to Early Cretaceous, 154-120 Ma)

uo - Umlekan-Ogodzhin arc (Cretaceous, 135-65 Ma)

\section{Active Arcs}

ib - Izu-Bonin (Late Cenozoic, 20-0 Ma)

ja - Japan (Late Cenozoic, 23-0 Ma)

kk - Kuril-Kamchatka (Late Cenozoic, 11-0 Ma)

\section{Transpressional Arcs}

mt - Mongol-Transbaikal (Late Triassic to Early Cretaceous, 230-96 Ma)

ss - South Siberian (Early Devonian, 415-400 Ma)

tr - Trans-Baikalian-Daxinganling (Middle Jurassic through Early Cretaceous, 175-96 Ma) 
Table 1. Definitions of key terms for the regional geologic and tectonic analysis of Northeast Asia. Adapted from Jones et al. (1983), Howell et al. (1985), and Nokleberg et al. (2000, 2003).

\begin{tabular}{|c|c|}
\hline Term & Definition \\
\hline Accretion & $\begin{array}{l}\text { Tectonic juxtaposition of terranes to a craton or craton or continental margin. Accretion of terranes to one another or } \\
\text { to a craton margin also definesa major change in the tectonic evolution of terranes and craton margins. }\end{array}$ \\
\hline $\begin{array}{l}\text { Accretionary-wedge } \\
\text { terrane }\end{array}$ & $\begin{array}{l}\text { Fragment of a mildly to intensely deformed complex consisting of varying amounts of turbidite deposits continental-margin, } \\
\text { rocks, oceanic crust and overlying units, and oceanic mantle. Units are interpreted to have formed during tectonic } \\
\text { juxtaposition in a zone of major thrusting of one lithosphere plate beneath another, generally in zones of thrusting along } \\
\text { the margin of a continent or an island arc. May include large fault-bounded fragments with a coherent stratigraphy. Many } \\
\text { subduction-zone terranes contain fragments of oceanic crust and associated rocks that exhibit a complex structural history, } \\
\text { occur in a major thrust zone, and possess blueschist-facies metamorphism. }\end{array}$ \\
\hline Amalgamation & Tectonic juxtaposition of two or more terranes before accretion to a continental margin. \\
\hline Craton & $\begin{array}{l}\text { Chiefly regionally metamorphosed and deformed shield assemblages of Archean and Early Proterozoic sedimentary, volcanic, } \\
\text { and plutonic rocks, and overlying platform successions of Late Proterozoic, Paleozoic, and local Mesozoic and } \\
\text { Cenozoic sedimentary and lesser volcanic rocks. }\end{array}$ \\
\hline Continent & $\begin{array}{l}\text { A large section of continental crust surrounded by oceans on all sides, which consist, in its core, of one } \\
\text { or more cratons framed by younger tectonic collages (accretionary and collisional orogenic belts). }\end{array}$ \\
\hline $\begin{array}{l}\text { Continental-margin } \\
\text { arc terrane }\end{array}$ & $\begin{array}{l}\text { Fragment of an igneous belt of coeval plutonic and volcanic rocks and associated } \\
\text { sedimentary rocks that formed above a subduction zone dipping beneath a continent. } \\
\text { Inferred to possess a sialic basement. }\end{array}$ \\
\hline Craton & $\begin{array}{l}\text { Chiefly regionally metamorphosed and deformed shield assemblages of Archean, Paleoproterozoic, and } \\
\text { Mesoproterozoic sedimentary, volcanic, and plutonic rocks, and overlying platform successions of } \\
\text { Paleoproterozoic, Paleozoic, and local Mesozoic and Cenozoic sedimentary and lesser volcanic rock. }\end{array}$ \\
\hline Craton margin & $\begin{array}{l}\text { Chiefly Neoproterozoic to Jurassic sedimentary rocks deposited on a continental shelf or slope. Consists mainly } \\
\text { of platform successions. Locally has, or may have had an Archean and Early Proterozoic cratonal basement. }\end{array}$ \\
\hline Cratonal terrane & Fragment of a craton. \\
\hline Island-arc system & An island arc and tectonically linked subduction zone terranes. \\
\hline Island-arc terrane & $\begin{array}{l}\text { Fragment of an igneous belt of plutonic rocks, coeval volcanic rocks, and associated sedimentary rocks that formed } \\
\text { above an oceanic subduction zone. Inferred to possess a simatic basement. }\end{array}$ \\
\hline Metamorphic terrane & $\begin{array}{l}\text { Fragment of a highly metamorphosed or deformed assemblage of sedimentary, volcanic, or plutonic rocks that cannot be } \\
\text { assigned to a single tectonic environment because the original stratigraphy and structure are obscured. Includes } \\
\text { intensely deformed structural melanges that contain intensely deformed fragments of two or more terranes. }\end{array}$ \\
\hline $\begin{array}{l}\text { Oceanic crust, } \\
\text { seamount, and } \\
\text { ophiolite terrane }\end{array}$ & $\begin{array}{l}\text { Fragment of part or all of a suite of deep-marine sedimentary rocks, pillow basalt, gabbro, and ultramafic rocks (former eugeoclinal } \\
\text { eugeoclinal suite) that are interpreted as oceanic sedimentary and volcanic rocks and the upper mantle. Includes both inferred } \\
\text { offshore oceanic and marginal ocean basin rocks, minor volcaniclastic rocks of magmatic-arc derivation, and major } \\
\text { marine volcanic accumulations formed at a hotspot, fracture zone, or spreading axis. }\end{array}$ \\
\hline
\end{tabular}

Overlap assemblage A postaccretion unit of sedimentary or igneous rocks deposited on, or intruded into, two or more adjacent terranes.

Passive continentalmargin terrane

Fragment of a craton (continental) margin.

Subduction zone terrane Fragment of a mildly to intensely deformed complex consisting of varying amounts of turbidite deposits, continental-margin rocks, oceanic crust and overlying units, and oceanic mantle. Units are interpreted to have formed during tectonic juxtaposition in a zone of major thrusting of one lithosphere plate beneath another, generally in zones of thrusting along the margin of a continent or an island arc. May include large fault-bounded fragments with a coherent . stratigraphy Many subduction-zone terranes contain fragments of oceanic crust and associated rocks that exhibit a complex structural history, occur in a major thrust zone, and possess blueschist-facies metamorphism.

Superterrane A series of amalgamated terranes and/or a rifted fragment of a craton and (or) craton margin which exhibits a long and complicated geologic history. May contain overlap island arc complexes and tectonically-linked subduction zones.

Tectonic collage A series of linear island arcs or continental margin arcs and tectonically-linked (companion) subduction zones, and (or) fore-arc and back-arc basins that formed in a major tectonic event during a relatively narrow geologic time span. The collages of igneous arcs and companion subduction zone terranes have been successively accreted to the margins of major cratons. The ages of collages with subduction zone units are for time of active formation of an accretionary wedge in a subduction zone, rather than the older range of units that comprise the accretionary wedge. A few collages consist of fragments of craton margin and cratonal terranes that were amalgamated before accretion to a continent.

Tectonic linkage A genetic relation of a continental margin arc or an island arc with a companion accretionary wedge that formed in a subduction zone that was adjacent to, and was underthrusting the arc.

Tectonostratigraphic terrane (terrane)

An aggregate of terranes that is interpreted to share either a similar stratigraphic kindred or affinity, or a common geologic history after accretion (Jones and others, 1983; Howell and others, 1985). An approximate synonym is composite terrane (Plafker and Berg, 1994).

Terrane A fault-bounded geologic entity or fragment that is characterized by a distinctive geologic history that differs markedly from that of adjacent terranes (Jones and others, 1983; Howell and others, 1985).

Turbidite terrane 
(2) passive continental margin; (3) metamorphosed continental margin; (4) continental-margin arc and back-arc; (5) island arc and back-arc; (6) oceanic crust, seamount, or ophiolite related to rifting and sea-floor spreading; (7) accretionary wedge and subduction zone; (8) turbidite basin; (9) collisional; (10) transform continental-margin faulting and associated bimodal volcanic-plutonic belt; (11) plume; and (12) metamorphic. For terranes with complex geologic and tectonic histories, the chosen tectonic environment is the one that was the most prevalent during the history of the terrane. The reader should refer to the associated citations for more detailed descriptions of these terranes with complex histories.

\section{Compilation of regional geodynamics map}

A regional geodynamics map was initially compiled at a scale of 1:5000000 (Nokleberg et al., 1997b, c; Parfenov et al., 2003, 2004a, b). However, in order to display major features of host rock geology and structures and major belts of mineral and hydrocarbon resources a page-size illustration, a summary regional geodynamics map (Fig. 2) was constructed at a scale of about 1:34000000 in order to display: (1) the regional surface extent of major geologic units (cratons, craton margins, tectonic collages of island arc, continental-margin arc, accretionary wedge, and passive continental margin terranes, volcanic and plutonic igneous arcs); (2) major fault and rift systems; and (3) active subduction zones. A list of major host-rock geologic units in the explanation and a description of major geologic units for the map is provided in Appendix A. The tectonic interpretations for the summary map are derived from the major publications of the collaborative international studies on Northeast Asia and the Circum-North Pacific (listed above).

\section{Methodology of regional geologic and tectonic analysis}

The methodology employed for synthesizing the summary geodynamics map consisted of: (1) correlation of major geologic units; (2) tectonic linking (pairing) of major geologic units; and (3) alignment of coeval arc and tectonicallylinked subduction zones into curvilinear complexes. A similar methodology was utilized for a synthesis of the CircumNorth Pacific (Nokleberg et al., 2000).

Initially, correlations are attempted for major geologic units which are interpreted as having been originally contiguous but were subsequently tectonically displaced during rifting, major thrusting, or along strike-slip faults. Correlations are attempted for all regional units (cratons, craton margins, terranes, and overlap assemblages) that are understood to have the same tectonic origin, (i.e., as parts of a single elongate passive continental margin, continental-margin arc, island arc, or subduction zone) at the same geologic time and originally on strike with each other. This correlation of major geologic units also illustrates the original continuity of rock units, provides important constraints on the past tectonics of the region, and provides a series of interpretations to be further evaluated by additional stratigraphic, geochemical, isotopic, paleomagnetic, and geophysical studies.

Following this step, tectonic linking (pairing) was based on pairing of: (1) subduction-related igneous arcs, now preserved as various igneous-arc terranes or overlap assemblages, with former subduction zones, now preserved as subduction-zone terranes; (2) belts of anatectic-related igneous rocks and major faults (sutures) that bound the collisional margins of terranes with each other or terranes with a craton margin; and (3) belts of igneous rocks that are coeval with, and occur along major transpressional fault zones.

The first type of tectonic linking can be based on: (1) recognizing an original physical proximity between an arc and subduction zone; (2) determining the similarity in age of formation of an igneous-arc and subduction-zone terrane, (3) determining a subduction polarity from tectonic transport direction in a melange for subduction-zone terranes, where not disrupted by later deformation, and (4) recognizing the occurrence of disrupted layers of arc-derived volcanic or volcaniclastic units from a specific igneous arc in the melange of the linked subduction zone terrane.

A second type of tectonic linking is based on the spatial and temporal association of collisional (S-type) granitic plutons and associated volcanic rocks with: (1) major fault zones (sutures) between terranes or between a terrane and a craton margin; and (or) (2) belts of highly deformed, regional-grade metamorphic rocks that occur along the fault zones. Collision-related igneous belts are understood as forming either during accretion of one terrane to another or during the accretion of one or more terranes to a craton margin.

A third type of tectonic linking is based on the spatial and temporal association of mainly intermediate and silicic igneous belts that are coeval with, and intrude along major transpressional fault zones.

Following these steps, terranes and overlap assemblages are grouped into larger entities that are understood to have been continuous, coeval igneous arcs and companion subduction-zones. This grouping of units is based, to varying degrees, on: (1) similar stratigraphy, fauna, rock-unit age, and structure; (2) paleomagnetic data, to a lesser degree; and (3) an assumption of simplicity. The result of these groupings is the alignment of coeval igneous-arc overlap assemblages and igneous-arc terranes, and tectonically-linked (companion) subduction-zone terranes into coeval, curvilinear arc-subduction-zone complexes. 


\section{Summary of regional geology and tectonics of Northeast Asia}

The major regional geologic and tectonic units of Northeast Asia are cratons, craton margins; cratonal terranes and superterranes; tectonic collages; overlap and transform continental-margin arcs; island arcs, and sea and ocean units (Fig. 2). Detailed descriptions of geologic units are presented by Nokleberg et al. (2000) and Parfenov et al. (2004b). Abbreviations in parentheses in the following list of geologic units refer to units on the summary geodynamics map (Fig. 2). More detailed descriptions of map units are given in Appendix A. Two geologic ages are staged for each collage, one for the age of formation of the units in a collage, such, and another age for the time of accretion (formation) of the collage to another terrane, superterrane, or continent.

\subsection{Major cratons and craton margins}

The backstop or core units for the region of Northeast Asia are the Archean and Proterozoic North Asia Craton and SinoKorean Craton and their Craton Margins (Baikal-Patom, Angara, South Taimyr, and Verkhoyansk (North Asian)).

The North Asian Craton (NAC) consists of Archean and Proterozoic metamorphic basement, and non-deformed, flatlaying platform cover consisting of Late Precambrian, Paleozoic, and Mesozoic sedimentary and volcanic rock.

The Sino-Korean Craton (SKC) consists of several major Archean and Proterozoic metamorphic basement terranes and younger Paleozoic through Cenozoic overlap units.

The Baikal-Patom Craton Margin (BP) consists of a faultbounded basin containing Riphean carbonate and terrigenous sedimentary rock, and younger Vendian and Cambrian sedimentary rock that discordantly overly a fragment of the preRiphean basement of the North Asian Craton.

The East Angara Craton Margin (EA) consists of Late Riphean terrigenous-carbonate sedimentary rock (sandstone, siltstone, mudstone with interlayered dolomite and limestone) that overlie a fragment of the North Asia Craton.

The South Taimyr Craton Margin (ST) consists chiefly of a thick wedge of Ordovician to Jurassic craton margin deposits and deep basin deposits.

The Verkhoyansk (North Asian) Craton Margin (VR) consists chiefly of a thick wedge of Devonian to Jurassic miogeoclinal deposits.

\subsection{Cratonal terranes and superterranes}

Three cratonal terranes occur along the margins of the North Asian and Sino-Korean Cratons and are understood as rifted and reaccreted fragments of these cratons, in contrast to exotic terranes which are understood to be far travelled. The cratonal terranes are as follows. (1) The Okhotsk terrane $(\mathrm{OH})$ terrane consists of Archean and Proterozoic gneiss and schist and Early and Middle Paleozoic miogeoclinal sedimentary rock. The terrane is considered to be a fragment of the North Asian Craton and Margin that was rifted in the Late Devonian or Early Carboniferous. (2) The GyenggiYeongnam terrane (GY) consists of two major Archean and Proterozoic basement rock terranes. The terrane is considered to be a displaced fragment of the Sino-Korean Craton. (3) The last of these terranes is the Jiaonan cratonal terrane (JA) which consists of a Paleoproterozoic major high pressure terrane that is interpreted as a displaced fragment of the Sino-Korean Craton.

Six superterranes occur along the margins of the North Asian and Sino-Korean Cratons. Some of the superterranes are considered to be rifted and reaccreted fragments of the cratons whereas others are understtod to having formed elsewhere.

The Proterozoic to Cambrian Argun-Idermeg superterrane (AR) consists of the Paleoproterozoic to Late Paleozoic Argunsky, Idermeg, and West Stanovoy metamorphosed passive continental-margin terranes. The superterrane may be either exotic with respect to the North Asian Craton or may be a rifted fragment of the craton.

The Late Riphean and older Tuva-Mongolia superterrane (TM) consists of a series of Archean and Paleoproterozoic cratonal terranes (Gargan and Baydrag), the Snagilen passive continental-margin terrane, and the Muya metamorphic terrane. These terranes are understood to have accreted together to form the rear or back arc part of the Baikal-Myra island arc described below.

The Proterozoic to Permian Bureya-Jiamusi supterterrane (BJ) consists of a collage of Early Paleozoic metamorphic, continental-margin arc, subduction zone, passive continental-margin and island arc terranes. The superterrane is considered to be a fragment of Gondwana that was accreted to the Sino-Korean Craton in the Late Permian and accreted to the North Asian Craton in the Late Jurassic during final closure of the Mongol-Okhotsk Ocean.

The Proterozoic to Ordovician Kara superterrane (KR) consists of the Late Neoproterozoic to Ordovician Kara continental-margin turbidite terrane. The superterrane is understood to be a rift fragment of the North Asian Craton that was reaccreted in the Jurassic.

The Archean to Jurassic Kolyma-Omolon superterrane (KOM) consists of a tectonic collage of cratonal, passive continental margin, island arc, ophiolite terranes. The cratonal and passive continental core of the superterrane was rifted from the North Asian Craton and Margin in Late Devonian or Early Carboniferous. After subsequent building of overlying island arcs, the superterrane was reaccreted to the North Asian Craton Margin in the Late Jurassic with formation of the collisional granites of the Main and Northern granite belts. 


\subsection{Tectonic collages between North Asian and Sino-Korean Cratons}

Between the North Asian and Sino-Korean Cratons are a series of accreted tectonic collages composed primarily of Paleozoic island arcs and tectonically-linked subduction zones. These tectonic collages were accreted successively from north to south during successive closures of the Paleo-Asian, Solon, and Mongol-Okhotsk Oceans. Most of the tectonic collages contain one or more island arcs and tectonicallylinked subduction zones. Because of successive terrane accretions from north to south, the ages of collages generally young from north to south. However, this pattern is locally interrupted because some collages or parts of collages were interspersed because of subsequent strike-slip faulting.

The tectonic collages between the North Asian and SinoKorean Cratons are as follows.

(1) The Circum-Siberia collage (CS) (Paleoproterozoic and Mesoproterozoic age and accreted in Neoproterozoic) consists of the Baikal-Muya island arc, the Near Yenisey Ridge island arc, and the Zavhan continental-margin arc, all of Neoproterozoic age, and small fragments of cratonal and metamorphic terranes of Archean and Proterozoic age. The three separate Neoproterozoic island arc systems formed south (present-day coordinates) of the North Asian Craton and Margin.

(2) The Yenisey-Transbaikal collage (YT) (Vendian to Devonian age and accreted in Vendian to Early Ordovician) consists of the Vendian to Middle Cambrian Kuznetsk-Tannuola, Dzhida-Lake island arc terranes, tectonically-linked backarc basins, and now tectonically-eroded subduction zone terranes. The collage contains a linear array of island arc systems that formed south (present-day coordinates) of the North Asian Craton and Margin and previously accreted terranes.

(3) The Altai collage (AL) (Vendian to Ordovician age and accreted in Late Silurian) consists of the Vendian to Early Ordovician Salair island arc and various fragments of arcrelated turbidite terranes, subduction zone terranes, metamorphic terranes derived from arc-related units, thick Cambrian and Ordovician overlap turbidite units that formed on a continental slope and rise, and fragments of originallyadjacent oceanic terranes. The collage is an island arc system that was active near the southwest margin (present-day coordinates) of the North Asian Craton and Margin and previously-accreted terranes.

(4) The Wundurmiao collage (WD) (Mesoproterozoic to Silurian age and accreted in Late Silurian) consists of the Late Ordovician to Silurian Laoling island arc terrane, the Mesoproterozoic to Middle Ordovician Wundurmiao subduction zone terrane, and the Neoproterozoic Seluohe subduction zone terrane. The collage contains the Laoling island arc system which formed near the Sino-Korean Craton. Both the island arc system and craton were widely separated from North Asian Craton in the Early Paleozoic.
(5) The Atasbogd collage (AB) (Ordovician to Permian age and accreted in Late Carboniferous or Early Permian) consists of: the Ordovician to Permian WaizungerBaaran terrane, the Devonian to Carboniferous BeitianshanAtasbogd terrane, and the Paleoproterozoic to Permian Tsagaan Uul-Guoershan continental-margin arc terrane. The collage was a southwest continuation (present-day coordinates) of the South Mongolia-Khingan island arc that formed southwest and west (present-day coordinates) of the North Asian Craton and Margin and previously accreted terranes. The Atasbogd collage was initially separated from the North Asian Craton by a large back-arc basin.

(6) The South Mongolia-Khingan collage (SM) (Ordovician to Carboniferous age and accreted in Late Carboniferous or Early Permian) consists of the South Mongolia-Khingan arc and tectonically-linked subduction zone terranes. The collage was a major island-arc system that formed southwest and west (present-day coordinates) of the North Asian Craton and Margin and previously accreted terranes. The collage was separated from the North Asian Craton by a large backarc basin.

(7) The West Siberian collage (WS) (Ordovician to Carboniferous age and accreted in Late Carboniferous or Early Permian) consists of the Late Silurian to Early Carboniferous Rudny Altai island arc, and the tectonically-linked Ordovician to Early Carboniferous Kalba-Narim subduction zone terrane. The collage is a northwest continuation (present-day coordinates) of the South Mongolia-Khingan collage.

(8) The Mongol-Okhotsk collage (MO) (Devonian to Late Jurassic age and accreted in Late Paleozoic to Early Mesozoic) consists mainly of the Permian to Jurassic Selenga, Late Carboniferous and Early Permian Hangay, and Uda-Murgal and Stanovoy continental-margin arcs. These arcs are composed of continental-margin igneous overlap assemblages, continental-margin turbidite terranes, and tectonically-linked, outboard subduction zone terranes. The arcs overlap the southern margin of the North Asian Craton and Margin, and previously-accreted terranes. The collage formed during long-lived closure of the Mongol-Okhotsk Ocean with oblique subduction of terranes beneath of southern North Asian Craton Margin and previously-accreted terranes.

(9) The Solon collage (SL) (Carboniferous to Permian age and accreted in Late Paleozoic to Early Mesozoic) consists of several subduction zone terranes: (1) Carboniferous and Early Permian North Margin terrane; (2) Late Carboniferous to Permian Solon terrane; (3) Devonian Imjingang terrane; (4) Paleozoic Ogcheon terrane; and (5) Silurian through Permian Sangun-Hidagaien-Kurosegawa terrane. Parts of the collage were fragments of the Solon Ocean plate that were subducted to form the South Mongolian, Lugyngol, Gobi-Khankaisk-Daxing' anling, and Jihei continental-margin arcs. Other parts of the collage are fragments of the Solon Ocean plate that were subducted to form 
the North Margin continental-margin arc on the Sino-Korean Craton.

\subsection{Tectonic collages east of North Asian and Sino-Korean Cratons}

To the east of the North Asian and Sino-Korean Cratons are a series of tectonic collages that were successively accreted from west to east (older to younger) during closures of parts of the Ancestral Pacific and modern Pacific Oceans, and older oceans in the region. Because of successive accretions from west to east, the ages of collages generally young from west to east. However, this pattern is locally disrupted because some collages have been tectonically disrupted and interspersed by subsequent strike-slip faulting

Except for the Verkhoyansk-Kolyma and Chukotka collages, the other tectonic collages contain one or more island arcs or continental-margin arcs and tectonically-linked subduction zones. The tectonic collages that occur east of the North Asian and Sino-Korean Cratons are the following.

(1) The Verkhoyansk-Kolyma collage (VK) (Late Paleozoic to Early Jurassic age and accreted in Late Jurassic to Early Early Cretaceous) consists of a deformed passive continental margin, accreted ophiolites, and subduction zone and formed during accretion of the outboard Kolyma-Omolon superterrane.

(2) The Chukotka collage (CH) (Paleozoic to Triassic age and accreted in Late Jurassic to Early Cretaceous) consists of passive continental-margin terranes that formed along the long-lived Neoproterozoic to Early Mesozoic North American Continental Margin. After subsequent rifting of the North American Craton Margin in the Late Jurassic and Early Cretaceous and translation, the collage was accreted to the northern Verkhoyansk-Kolyma collage in the Late Cretaceous.

(3) The South Anyui collage (SA) (Permian to Early Jurassic age and accreted in Late Cretaceous) consists of the Oloy island arc and tectonically-linked subduction zone terranes.

(4) The Penzhina-Anadyr collage (PA) (Late Jurassic to Early Cretaceous age and accreted in Late Cretaceous) consists of the Murgal island arc terrane and tectonically-linked subduction zone terranes to the east. The collage rims the eastern Kolyma-Omolon superterrane and VerkhoyanskKolyma collage. The collage is also linked to the Uda continental-margin arc.

(5) The Badzhal collage (BD) (Triassic to Early Cretaceous age and accreted in Late Cretaceous) consists of the Umlekan continental-margin arc and tectonically-linked subduction zone terranes to the east with Tethyan fauna.

(6) Honshu-Sikhote-Alin collage (HS) (Jurassic and Early Cretaceous age and accreted in Cretaceous). This collage consists of fragments of island arc, continental-margin turbidite (flysch), and subduction zone terranes. The collage formed along a transform continental margin.
(7) The Koryak collage (KOR) (Late Triassic to Cretaceous age and accreted in Late Cretaceous) consists of the Late Jurassic and Early Cretaceous Manitskiy island arc and tectonically-linked subduction zone terranes to the east.

(8) The Sakhalin-Hokkaido collage (SK) (Cretaceous age and accreted in Eocene) consists of the Late Cretaceous flysch terranes of Sakhalin and Hokkaido Islands, and tectonically-linked subduction zone terranes to the east. The collage formed a continental-margin fore-arc basin and tectonically-linked subduction zone terranes that are associated with the East Sikhote-Alin continental-margin arc.

(9) The West Kamchatka collage (WK) (Mid-Cretaceous to Early Tertiary age and accreted in Early Cenozoic) consists of Late Paleozoic to Cretaceous subduction zone terranes in the Russian Northeast. The collage was tectonically linked to Okhotsk-Chukotka continental-margin arc.

(10) The East Sakhalin collage (ES) (Late Cretaceous to Early Tertiary age and accreted in Early Tertiary) consists of the Late Cretaceous to Middle Eocene Terpeniy-TokoroNemuro-Shmidt island arc and tectonically-linked subduction zone terranes.

(11) The Olyutorka-Kamchatka collage (OK) (Late Cretaceous and Paleocene age and accreted in Early Cenozoic) consists of the Olyutorka island arc and tectonically-linked subduction zone terranes to the east.

(12) The East Kamchatka Peninsula collage (EP) (mainly Paleocene age and accreted in Pliocene) consists of the Kronotskiy island arc and associated ophiolite.

\subsection{Carboniferous and Permian overlap continental- margin arcs occurring south of North Asia Craton and on Sino-Korean Craton}

Several major overlap continental-margin arcs occur only on previously-accreted terranes south of the North Asian Craton and on the Sino-Korean Craton. These arcs are related to subduction of the Late Paleozoic and Early Mesozoic Solon Ocean plate beneath the North Asian and Sino-Korean Cratons. This ocean occurred (in present-day geographic coordinates) between the Argun-Idermeg superterrane to the north and the Sino-Korean Craton to the south. The arcs are described progressing from older to younger.

(1) The Altay arc (at) (Devonian and Early Carboniferous) occurs on the Altay and Yenisey-Transbaikal collages. The arc formed along an active continental margin in an oblique subduction zone environment.

(2) The Gobi-Khankaisk-Daxing'anling arc (gh) (Permian) occurs on the Argun-Idermeg superterrane, South Mongolian collage, and Solon collage. The arc formed during subduction of the northern part of Solon Ocean plate under the southern margin (present-day coordinates) of the Argun-Idermeg superterrane.

(3) The South Mongolian arc (sm) (Middle Carboniferous through Triassic) overlies and intrudes the South Mongolian collage and Atasbogd collage. The arc formed during 
subduction of the northern part of Solon Ocean plate under the Argun-Idermeg superterrane.

(4) The Lugyngol arc (lg) (Permian) occurs on the South Mongolian and Solon collages. The arc is formed during subduction of the northern part of Solon Ocean plate under the southern margin (present-day coordinates) of the ArgunIdermeg superterrane.

(5) The Jihei arc (ji) (Permian) occurs on the South Mongolia-Khingan collage. The arc intrudes the BureyaJiamusi superterrane and South Mongolia-Khingan collage and formed during subduction of the northern part of Solon Ocean plate under the southern margin (present-day coordinates) of the Bureya-Jiamusi supterterrane and adjacent units.

(6) The North Margin arc (nm) (Late Carboniferous to Permian) occurs on the northeastern margin (present-day coordinates) of Sino-Korean Craton. The arc formed during subduction of the southern part of Solon Ocean plate under the northeastern margin (present-day coordinates) of SinoKorean Craton.

\subsection{Devonian to Early Cretaceous overlap continental- margin arcs occurring along Southeastern Margin of the North Asian Craton and adjacent accreted terranes}

Several major overlap continental-margin arcs occur along the southeastern margin of the North Asian Craton or on adjacent accreted terranes. The arcs are related to subduction of the Late Paleozoic and early Mongol-Okhotsk Ocean plate beneath the North Asian Craton and Margin. This ocean occurred between the North Asian Craton to the north and the Argun-Idermeg superterrane to the south (present-day coordinates).

(1) The Norovlin arc (nr) (Devonian to Early Carboniferous) occurs on the Argun-Idermeg superterrane (Amur microcontinent - Argunsky and Idermeg passive continentalmargin terranes). The arc is formed during subduction of the Mongol-Okhotsk Ocean plate beneath northern margin (in present-day geographic coordinates) of the Argun-Idemeg superterrane (Amur microcontinent).

(2) The Hangay arc (ha) (Late Carboniferous to Early Permian) occurs on the Yenisey-Transbaikal collage and Mongol-Okhotsk collage. The arc formed during subduction of the northern part of Mongol-Okhotsk Ocean plate under the North Asian Craton Margin and previously-accreted terranes.

(3) The Selenga arc (se) (Permian to Jurassic) overlies and intrudes the Yenisey-Transbaikal collage and Tuva-Mongolia superterrane. The arc formed during oblique subduction of the Mongol-Okhotsk Ocean plate under the North Asian Craton Margin and previously-accreted terranes.

(4) The Uda-Murgal and Stanovoy arcs (us) (Jurassic to Early Cretaceous) occur on the southern margin of the North
Asian Craton. The arcs formed during final stage of subduction of the Mongol-Okhotsk Ocean plate.

\subsection{Jurassic and Early Cretaceous overlap island arcs occurring on or adjacent to Kolyma-Omolon superterrane}

The major overlap island arcs occurring on the KolymaOmolon superterrane are the Late Jurassic to Early Cretaceous Uyandina-Yasachnaya island arc and the Late Jurassic Oloy island arc

(1) The Uyandina-Yasachnaya arc (uy) (Late Jurassic to Early Cretaceous) occurs along the margin of the KolymaOmolon superterrane. The arc formed during subduction of the Oimyakon Ocean plate between the North Asian Craton Margin and the Kolyma-Omolon superterrane. Remnants of the Oimyakon oceanic crust are preserved in small obducted ophiolites along the western margin of superterrane. This ocean occurred between the Verkhoyansk (North Asian) Craton Margin to the southwest and the Kolyma-Omolon to the northeast (present-day coordinates).

(2) The Oloy arc (ol) (Late Jurassic) occurs along the margin of the Kolyma-Omolon superterrane. The arc formed on the Kolyma-Omolon superterrane during subduction of the South Anyui Ocean plate beneath the superterrane to form the South Anyui subduction-zone terrane. This ocean formed north of the Kolyma-Omolon superterrane (present-day coordinates).

\subsection{Jurassic through Early Tertiary overlap continental-margin arcs and granite belts occurring along eastern margin of Northern Asia}

A series of Jurassic through Early Tertiary overlap continental-margin arcs and granite belts occur along the eastern margin of the North Asian and Sino-Korean Cratons and outboard accreted terranes to the east. From older to younger, the arcs and belts are as follows.

(1) The Umlekan-Ogodzhin arc (uo) (Jurassic and Cretaceous) occurs along the margin of the Kolyma-Omkolon superterrane. The arc formed during subduction of the Ancestral Pacific Ocean plate to form the Badzhal and Nadanhada terranes in the Badzhal collage.

(2) The South Verkhoyansk Granite Belt (sv) (Late Jurassic to Mid-Cretaceous) occurs in the Central Russian Far East. The belt extends longitudinally along the central part of the South Verkhoyansk synclinorium in the Verkoyansk (North Asian) Craton Margin. The belt formed during the accretion of the outboard Okhotsk terrane.

(3) The Main Granite Belt (ma) (Late Jurassic) occurs along the adjacent margins of the North Asian Craton Margin and Kolyma-Omolon superterrane. The belt formed during and immediately after the collision of the Kolyma-Omolon superterrane with the North-Asian Craton Margin. 
(4) The Transverse Granite Belt (tr) (Early Cretaceous) radiates outwards from the southwestern bend of the KolymaOmolon superterrane. The belt formed during the late stage of accretion of Kolyma-Omolon superterrane.

(5) The Northern Granite Belt (nb) (Early Cretaceous, 138 to $120 \mathrm{Ma}$ ) occurs along northwestern margin of the KolymaOmolon superterrane. The belt formed during the subduction of oceanic crust during a closure of a small oceanic basin during late stage of accretion of Kolyma-Omolon superterrane.

(6) The Khingan-Okhotsk arc (ko) (Early and MidCretaceous) occurs in the Russian Southeast and consists of the Khingan-Okhotsk volcanic-plutonic belt. The arc was tectonically paired to the Early Cretaceous ZhuravlevskAmur River and Kiselevka-Manoma subduction-zone terranes that are both part of the Honshu-Sikhote-Alin collage.

(7) The Okhotsk-Chukotka arc (oc) (Late Cretaceous to Early Tertiary) occurs along the eastern margin of the Central and Northern Russian Far East. The arc formed during subduction of the Ancestral Pacific Ocean plate and formation of the West Kamchatka, Ekonay, and Yanranay subduction zone terranes.

(8) The East Sikhote-Alin arc (ea) (Late Cretaceous to Early Tertiary) occurs along the margin of the Southern Russian Far East. The arc formed during subduction of the Ancestral Pacific Ocean plate with formation of the older part of the Hidaka subduction zone, the younger part of the Aniva subduction-zone terrane, and the Nabilsky, and Tokoro subduction-zone terranes.

\subsection{Active overlap continental-margin arcs occurring along eastern margin of Northern Asia}

Three active overlap continental-margin arcs occur along the eastern margin of the North Asian and Sino-Korean Cratons and outboard accreted terranes to the east.

(1) The Izu-Bonin arc (ib) (Miocene through Present) occurs south of Southern Japan and consists of a volcanic arc composed chiefly of basalt to rhyolite, associated volcaniclastic rock, and intercalated hemipelagic mudstone. The arc is formed during subduction of the Philippine Sea Plate with formation of the Nankai subduction zone. (2) The Japan arc (ja) (Miocene through Present) occurs along the Japanese Islands and consists of extensive Quaternary volcanic and associated rock. The arc is formed during subduction of the Pacific Ocean and Philippine Sea Plates with formation of the Japan Trench and Nankai subduction zones.

(3) The Kuril-Kamchatka arc (kk) (Miocene through Present) occurs along Kamchatka Peninsula and Kuril Islands and consists of the Pliocene to Quaternary Central Kamchatka volcanic belt, Central Kamchatka volcanic and sedimentary basin, and the East Kamchatka volcanic belt. The arc is formed during subduction of the Pacific Ocean Plate and formation of the Japan Trench subduction zone.

\subsection{Transpressional arcs (Devonian through Cretaceous)}

Three major transpressional arcs occur along the margins of the North Asian Craton and previously accreted terranes to the south. The arc formations are associated with strike-slip faulting that is sometimes associated with local compression and extension.

(1) The South Siberian arc (ss) (Early Devonian) occurs in Southern Siberia. The arc is formed along the southern margin of the North Asian Craton and Craton Margin during Early Devonian rifting that successively evolved into a continental-margin transform margin and subsequently into a convergent margin.

(2) The Mongol-Transbaikal arc (mt) (Late Triassic to Early Cretaceous) occurs in Northern Mongolia and Southern Siberia. The arc is formed during strike-slip faulting and rifting along the Mongol-Okhotsk fault during and after the final closure of the Mongol-Okhotsk Ocean.

(3) The Trans-Baikal-Daxinganling arc (tr) (Middle Jurassic through Early Cretaceous) occurs in Southern Siberia, Mongolia, Northeastern China. The arc formed during strike-slip faulting and rifting along the Mongol-Okhotsk fault during, and after the final closure of the MongolOkhotsk Ocean.

\section{Conclusions}

Compiled with the methodology described herein, the Northeast Asia summary geodynamics map (Fig. 2) illustrates the power of a regional map and provides an example for future regional studies of large parts of the earth's continental crust. This map greatly benefits the interpretation of origins of major rock units, major structures, and mineral and hydrocarbon resources, and provides important guidelines for new research.

\section{Appendix A}

\section{Description of map units for Northeast Asia summary geodynamics map}

\section{A1 Introduction}

The major map units on the Northeast Asia summary geodynamics map are cratons, craton margins, cratonal terranes, superterranes, tectonic collages (Archean to Proterozoic, Vendian to Cretaceous, Late Cretaceous and Cenozoic), overlapping continental-margin arcs (Devonian to Early Tertiary), transform continental-margin arcs (Devonian to Early Cretaceous), active arcs (Miocene through Present), and active subduction zones (Miocene through Present). Units are listed in order of map unit abbreviations within each major unit. Additional information about the map units can be found in Greninger et al. (1999), Nokleberg et al. (1994, 1997c, 2000, 2004), and Naumova et al. (2006). 


\section{A2 Cratons}

NAC - North Asian Craton (Archean and Proterozoic). Consists of Archean and Proterozoic metamorphic basement, and non-deformed, flat-laying platform cover consisting of Late Precambrian, Paleozoic, and Mesozoic sedimentary and volcanic rock. Cover locally ranges up to $14000 \mathrm{~m}$ thick. Metamorphic basement exposed in the Aldan-Stanovoy and Anabar shields located near southern and northern craton margins, respectively. Along the southwestern margin of the craton is a narrow band of basement rocks named the NearSayan Uplift. Within the Aldan-Stanovoy and Anabar shields and the Near-Sayan Uplift are several terranes composed of Early Precambrian crystalline rocks of varying composition and structural style. Four sequences comprise the platform cover: (1) Vendian and Early Paleozoic; (2) Middle Paleozoic; (3) Late Paleozoic; and (4) Mesozoic. Each stage is characterized by a unique structural style and unique suite of sedimentary and magmatic rocks. The sequences are separated from each other by regional discontinuities and unconformities that are related to major tectonic events.

SKC - Sino-Korean Craton (Archean and Proterozoic). Consists of several major terranes and younger overlap units in Northern China and in the northern Korean Peninsula. The Archean and Proterozoic metamorphic basement is composed of various major terranes and first overlap units: (1) Paleoproterozoic Alashan granuliteparagneiss terrane in Northwestern China; (2) Archean Erduosi Granulite-paragneiss terrane in North-Central China; (3) Archean Yinshan granite-greenstone terrane and first overlapped Zhangbei-Bayan Obo-Langshan metasedimentary and metavolcanic rocks (Paleo-Mesoproterozoic) in North-Central China; (4) Archean Jilin-Liaoning-East Shandong tonalite-trondhjemite-gneiss terrane and overlapped, metamorphosed and deformed rocks of East Shandong-East Liaoning-East Jilin rift or foreland basin (Paleoproterozoic) in Northeastern China; (5) Archean West Liaoning-HebeiShanxi granulite-orthogneiss terrane and overlapped, metamorphosed and deformed rocks of Hutuo rift basin (Paleoproterozoic) in Northern China; (6) Archean to Paleoproterozoic Machollyong granulite-paragneiss terrane in Northern Korean Peninsula; and (7) Archean Rangnim granuliteparagneiss terrane in Northern Korean Peninsula. Overlap units are extensive Proterozoic and Paleozoic continentalmargin sedimentary rock and lesser volcanic rock; and extensive Mesozoic and Cenozoic marine and terriginous sedimentary rock units, and volcanic and plutonic arc rock units.

\section{A3 Craton margins}

BP - Baikal-Patom Craton Margin (Riphean to Cambrian and older basement). Consists of a fault-bounded basin containing Riphean carbonate and terrigenous sedimentary rock, and Younger Vendian and Cambrian sedimentary rock that discordantly overly a fragment of pre-Riphean basement of the North Asian Craton. Local detritus suggests derivation from ophiolite and island arc complexes of the Bakal-Muya terrane during accretion to the craton. Local greenschist and amphibolite facies regional metamorphism with isotopic ages of about $800 \mathrm{Ma}$.

EA - East Angara Craton Margin (Riphean and older basement). Consists of Late Riphean terrigenous-carbonate sedimentary rock (sandstone, siltstone, mudstone with interlayered dolomite and limestone) that overlie a fragment of the North Asia Craton. Metamorphosed up to greenschist facies. Unconformably overlapped by Late Riphean and Vendian molasse and Vendian and Cambrian dolomite and limestone.

ST - South Taimyr Craton Margin (Ordovician to Jurassic). Consists chiefly of a thick wedge of craton margin deposits and deep basin deposits ranging up to $20000 \mathrm{~m}$ thick. Composed chiefly of Ordovician to Jurassic clastic rock, shallow-marine terrigenous and carbonate rock, and mafic volcanic and volcaniclastic rock. Late Carboniferous and Permian sedimentary rocks contain extensive sills and dikes of the Early Triassic trap subalkaline and alkaline diabase. The terrane is tectonically detached from the crystalline basement of the North Asian Craton but was subsequently accreted back onto the craton.

VR - Verkhoyansk (North Asian) Craton Margin (Devonian to Jurassic). Consists chiefly of a thick wedge of cratonal margin deposits ranging up to $20000 \mathrm{~m}$ thick. Major units are Carboniferous, Permian, Triassic, and Early and Middle Jurassic clastic rock, and marine-littoral, deltaic, and shelf sedimentary rock deposited on the Verkhoyansk passive continental margin of the North Asian Craton. Major units grade successively eastward into turbidite deposits and deep-water black shale. Also occurring are: (1) local Middle to Late Devonian and Early Carboniferous, rift-related deposits similar to those on the Siberian Platform; and (2) local Early Triassic and Early Jurassic alkalic basalt flows, dikes, and sills. Northern and southern parts of craton margin contain thick, Neoproterozoic and Early Paleozoic shallowmarine carbonate and clastic deposits that are finer-grained and thicker to east. The terrane is tectonically detached from the passive continental margin and crystalline basement of the North Asian Craton.

\section{A4 Cratonal terranes}

GY - Gyenggi-Yeongnam cratonal terrane (Archean and Proterozoic). Consists of two major terranes: (1) Mesoproterozoic and Neoproterozoic and older Gyenggi granuliteparagneiss terrane in Southern Korean Peninsula; and (2) Late Archean to Paleoproterozoic Yeongnam granuliteparagneiss terrane in Southern Korean Peninsula. Locally overlain by extensive Paleozoic continental margin sedimentary rock and lesser volcanic rock; and extensive Mesozoic and Cenozoic marine and terriginous sedimentary rock units, and volcanic and plutonic arc units. The terrane is interpreted as a displaced fragment of the Sino-Korean Craton. 
JA - Jiaonan cratonal terrane (Proterozoic). Consists of a Paleoproterozoic major high pressure terrane that is a displaced fragment of the South China (Yangtzi) Craton. Locally overlain by extensive Paleozoic continental margin sedimentary rock and lesser volcanic rock, extensive Mesozoic and Cenozoic marine and terriginous sedimentary rock units, and volcanic and plutonic arc units.

$\mathrm{OH}$ - Okhotsk cratonal terrane (Archean, Proterozoic, and Early and Middle Paleozoic). Consists chiefly of large blocks of Archean to Paleoproterozoic gneiss and schist with a U$\mathrm{Pb}$ zircon age of $3.7 \mathrm{Ga}$. Overlain by: (1) gently-dipping, shallow-marine Middle and Neoproterozoic clastic and carbonate rock; (2) Early Cambrian limestone, marl, and sandstone; (3) Early Ordovician conglomerate, limestone, marl, and sandstone; and (4) unconformably overlying Middle Devonian limestone, sandstone, shale, and conglomerate, and Late Devonian rhyolite, ignimbrite, andesite, dacite, and tuff that are interlayered with nonmarine sandstone, siltstone, and conglomerate. Overlying units are Carboniferous to Late Jurassic nonmarine and rare marine clastic rock. The terrane is interpreted as a fragment of the North Asian Craton and Craton margin that was rifted in the Late Devonian or Early Carboniferous and accreted to the Eastern Asia continental margin in the Late Jurassic.

\section{A5 Superterranes}

AR - Argun-Idermeg superterrane (Proterozoic to Cambrian; Timing of accretion - Late Neoproterozoic to Cambrian). Consists of: (1) Paleoproterozoic to Late Paleozoic Argunsky metamorphosed passive continental margin terrane (AR) (Eastern Mongolia, Northeastern China, Transbaikalia); (2) Proterozoic to Cambrian Idermeg metamorphosed passive continental margin terrane (ID) (Eastern Mongolia); and (3) West Stanovoy metamorphosed continental margin terrane (WST) (Archean through Neoproterozoic) (Transbaikalia, Mongolia). The superterrane metamorphosed at greenschist to upper amphibolite to granulite facies.

BJ - Bureya-Jiamusi supterterrane (Proterozoic to Permian; Timing of accretion - Early Paleozoic). Consists of an Early Paleozoic collage with fragments of the following metamorphic, continental-margin arc, subduction zone, passive continental-margin and island arc terranes: (1) Neoproterozoic to Triassic Bureya terrane (BU) (the Southern Russian Far East); (2) Neoproterozoic and older and Early Cambrian Jiamusi terrane (JI) (Northeastern China); (3) Proterozoic Matveevka terrane (MT) (the Southern Russian Far East); (4) Proterozoic Nakhimovka terrane (NK) (the Southern Russian Far East); (5) Silurian to Permian(?) South Kitakami metamorphosed island arc terrane (SK) (Northern Honshu Island, Japan); and (6) Late Carboniferous and Permian Laoyeling-Grodekov island arc terrane (LG) (Northeastern China, the Southern Russian Far East); (7) Cambrian through Permian passive continental-margin Voznesenka terrane (the Southern Russian Far East); (8) Cambrian(?) and
Ordovician(?) Sergeevka island arc terrane (SG) (the Southern Russian Far East); (9) Neoproterozoic through Devonian Zhangguangcailing continental-margin arc terrane (ZN) (Northeastern China); (10) Ordovician and Silurian Heilongjiang subduction zone, type B terrane (HE) (Northeastern China); (11) Archean through Middle Triassic Urmi passive continental margin terrane (UR) (Northeast China, the Southern Russian Far East); and (12) Late Carboniferous and Permian Tumangang island arc terrane (TB) (Korea). These terranes are derived from a series of Late Precambrian volcanic units, and Late Precambrian to Ordovician shallow marine clastic and carbonate rock. Local amphibolite and granulite facies metamorphism of Early and Middle Ordovician age (480 to $500 \mathrm{Ma}$ ). Units intruded by Cambrian and Ordovician granitoids and unconformably overlain by Devonian rock.

The superterrane is interpreted as a fragment of Gondwana that was accreted to the Sino-Korean Craton in the Late Permian and accreted to the North Asian Craton in the Late Jurassic during closure of the Mongol-Okhotsk ocean. The superterrane may be a fragment of the Yenisey-Transbaikal orogenic belt that also contains Early Paleozoic granulite facies metamorphism and Cambrian and Ordovician granitoids.

KR - Kara superterrane (Proterozoic to Ordovician; Timing of accretion - Early Paleozoic(?). Consists of a Late Neoproterozoic to Ordovician Kara continental-margin turbidite terrane (KR) (northern part of Taimyr Peninsula). The terrane contains mainly Late Riphean turbidite units metamorphosed up to amphibolite facies. Uppermost turbidites contain Cambrian and Early Ordovician fauna. Turbidites are unconformably overlain by Ordovician-Devonian littoral-marine and continental sedimentary rock. The superterrane accreted to the North Asian Craton (with genesis of) generating Middle Permian two-mica and biotite-amphibole granite and granodiorite (with $\mathrm{U}-\mathrm{Pb}, \mathrm{Rb}-\mathrm{Sr}$, and incremental Argon isotopic ages of 264 to $252 \mathrm{Ma}$ ). Granitoids comprise an extensive belt that obliquely cuts the superterrane and the margin of the Late Riphean Circum-Siberian collage. The superterrane is interpreted as a rifted fragment of the North Asian Craton that was reaccreted in the Jurassic.

KOM - Kolyma-Omolon superterrane (Archean to Jurassic; Timing of accretion - Late Jurassic). Consists of a collage of cratonal, passive continental-margin, island arc, and ophiolite terranes. Major terranes are: Alazeya (island arc), Aluchin (subduction zone), Argatass (turbidite), Beryozovka (turbidite), Kenkel'da (subduction zone), Khetachan (island arc), Munilkan (oceanic), including various small ophiolite fragments (Garbyn'ya, Indigirka, Kybytygas, Munilkan, Uyandina, Uvyazka), Nagondzha (turbidite), Oloy (island arc), Omolon (cratonal), Omulevka (continental margin), Prikolyma (continental margin), Uyandina (island arc), and Yarkvaam (island arc). The superterrane formed during accretion of terranes of cratonal, continental (Omulevka, Prikolyma, and Omolon terranes), and oceanic affinity to the 
Alazeya island arc. Obduction of oceanic crust and formation of small ophiolite fragments of the Munilkan terrane were associated with this process. The superterrane is unconformably overlain by the Late Jurassic Uyandina-Yasachnaya superterrane marginal arc (uy) under which the Oimyakon ocean basin was subducted during migration of superterrane towards the North Asia (Verkhoyansk) Craton Margin. The superterrane was accreted to the northeast Verkhoyansk (North Asian) Craton Margin in the Late Jurassic to Early Cretaceous. The accretion resulted in formation of collisional granites of the Main (mb) (Late Jurassic) and Northern (nb) (Early Cretaceous) granite belts (Yakutia).

TM - Tuva-Mongolia superterrane (Late Riphean and older; Timing of accretion - Late Neoproterozoic). Consists of many fragments of the: (1) Archean and Paleoproterozoic Gargan cratonal terrane (GG) (North Huvsgol, Mongolia, Eastern Sayan); (2) Proterozoic Sangilen passive continental-margin terrane (SA) (Southwest Siberia, Mongolia); (3) Neoproterozoic and older Baydrag cratonal terrane (BY) (Northwest Mongolia); and (4) Late Archean(?) and Paleoproterozoic(?) Muya metamorphic terrane (MS) (Transbaikalia). The superterrane also includes the various terranes of the Baikal-Muya island arc system (Baikal-Muya, Barguzin, Dibinsky, Hug, Ilchir, Kuvai, Olokit-Delunuran, and Sarkhoy terranes) that were amalgamated to form the Tuva-Mongolian microcontinent. The superterrane is unconformably overlain by Vendian and Cambrian sedimentary and volcanic rock.

\section{A6 Tectonic collages accreted between North Asian and Sino-Korean Cratons (Proterozoic to Early Mesozoic accretions}

AB - Atasbogd collage (Ordovician to Permian; Timing of accretion - Late Carboniferous or Early Permian). Consists of: (1) Ordovician to Permian Waizunger-Baaran terrane; (2) Devonian to Carboniferous Beitianshan-Atasbogd terrane; and (3) Paleoproterozoic to Permian Tsagaan UulGuoershan continental-margin arc terrane; The collage is a southwest continuation (present-day geographic coordinates) of the South Mongolia-Khingan island arc. Units in the collage are unconformably overlain by Permian volcanogenic and coal-bearing units. The collages comprising the arcs were accreted to the southern margin of the Siberian continent in the Late Carboniferous or Early Permian (320 to $300 \mathrm{Ma})$.

AL - Altai collage (Vendian to Ordovician; Timing of accretion - Late Silurian). Consists of Vendian to Early Ordovician Salair island arc and various fragments of arcrelated turbidite, and subduction zone terranes, metamorphic terranes derived from arc-related units, and thick Cambrian and Ordovician overlap turbidite units formed on continental slope and rise, and fragments of originally-adjacent oceanic terranes are the major units in the collage. The collage is an island arc system that lay near the southwest margin (present-day coordinates) of the North Asian Craton and Margin and previously-accreted terranes. These units occur in the Gorny Altai, West Sayan, Central and Northwestern Mongolia, and adjacent regions of Northern China.

The Salair island arc (Vendian-Early Ordovician) is preserved in various fragments in Southwestern Siberia in the: (1) Early Cambrian to Early Ordovician Salair island arc terrane; (2) the Cambrian Ulus-Cherga island arc terrane; and (3) Early and Middle Cambrian Sugash terrane. The tectonically-linked subduction zone and oceanic crust units are the: (1) Vendian and Early Cambrian Alambai subduction zone terrane; and (2) Late Neoproterozoic to Early Cambrian Baratal subduction zone terrane.

The arc is also preserved in various fragments in the following metamorphic (arc-related) terranes: Middle Silurian and older Angurep terrane; Late Permian and older Belokurikha terrane; and Mesoproterozoic and Neoproterozoic Qinghe-Tsel terrane.

The arc is also preserved in various fragments of the following continental-margin turbidite terranes: Early to Late Paleozoic Anui-Chuya terrane; Precambrian and Cambrian to Devonian Altai terrane; Cambrian to Devonian Charysh terrane; Late Neoproterozoic to Devonian West Sayan terrane; and Neoproterozoic through Silurian Hovd terrane.

The arc is tectonically linked to various fragments in the following subduction zone terranes: Early Paleozoic or older Kaitanak terrane; Middle Devonian or older Maralikha terrane; Late Neoproterozoic through Early Cambrian Terekta terrane; and Late Neoproterozoic to Early Cambrian Baratal terrane.

The arc is also tectonically linked to various fragments of the following oceanic terranes: Late Neoproterozoic and Early Cambrian Mogen-Buren terrane; Late Cambrian and Early Ordovician Zasurin terrane; and Late Neoproterozoic and Early Cambrian Saratan terrane.

The timing of the accretion of the collage to the Siberian continent is constrained by an angular unconformity at the base of the Upper Silurian or Devonian units and by orogenic granitoid magmatism of Early Devonian or older (preEmsian) age (about 435-415 Ma).

CS - Circum-Siberia collage (Proterozoic; Timing of accretion - Neoproterozoic). The collage consists of the Baikal-Muya island arc, the Near Yenisey Ridge island arc, the Zavhan continental-margin arc, Central and West Angara passive continental-margin terranes, all of Neoproterozoic age, and small fragments of cratonal and metamorphic terranes of Archean and Proterozoic age. The collage consists of three separate Neoproterozoic island arc systems that formed south (present-day geographic coordinates) of the North Asian Craton and Margin and previously accreted terranes. The collage is unconformably overlain by Vendian and Cambrian sedimentary rock units, similar to coeval rocks of the Siberian platform, but much thicker and containing more marine units. Accretion of the collage to 
the North Asian Craton and Craton Margin occurred in the Late Neoproterozoic.

Baikal-Muya island arc (Neoproterozoic). Preserved in various fragments in the: (1) Paleoproterozoic to Early Cambrian Hamar-Davaa metamorphic terrane (metamorphosed forearc prism); (2) Neoproterozoic Baikal-Muya island arc terrane; (3) Late Neoproterozoic Barguzin metamorphic terrane (metamorphosed forearc prism); and (4) Late Neoproterozoic Sarkhoy island arc terrane. The tectonicallylinked subduction zone or subduction zone units are the: (1) Paleoproterozoic to Neoproterozoic Olokit-Delunuran subduction zone terrane; (2) Neoproterozoic Hug subduction zone terrane; and (3) Neoproterozoic Kuvai subduction zone terrane.

Near Yenisey Ridge island arc (Neoproterozoic). Preserved in various fragments in the: (1) Neoproterozoic Isakov island arc terrane; (2) Late Neoproterozoic Predivinsk island arc terrane; and (3) Neoproterozoic Chelyuskin island arc terrane.

Zavhan continental-margin arc (Neoproterozoic). Preserved in various fragments in Northern Mongolia in the: (1) Late Neoproterozoic Zavhan continental-margin arc terrane; and (2) Neoproterozoic Tasuul oceanic terrane.

Cratonal and Metamorphic terranes (Archean and Proterozoic). Consists mainly of relatively small (tens of kilometers wide) fragments preserved in the: (1) Archean and Paleoproterozoic Gargan cratonal terrane; (2) Late Archean(?) and Paleoproterozoic(?) Muya metamorphic terrane; and (3) Paleoproterozoic Kan cratonal terrane. The terranes are fragments of the North Asian Craton and that were rifted away during the breakup of the Rodinia supercontinent. These cratonal and metamorphic terranes formed a tectonic backstop for the accretion of the Neoproterozoic island arcs in the Circum-Siberia collage.

MO - Mongol-Okhotsk collage (Devonian to Late Jurassic; Timing of accretion - Late Paleozoic to Early Mesozoic). Consists mainly of Middle to Late Paleozoic and Early Mesozoic Selenga, Hangay, and Uda-Murgal and Stanovoy continental-margin arcs composed of continental-margin igneous overlap assemblages, continental-margin turbidite terranes, and tectonically-linked outboard subduction zone terranes. The arcs overlap the southern margin of the North Asian Craton and Margin and previously-accreted terranes.

The major continental-margin arc overlap units in the collage are the: (1) Permian to Jurassic Selenga sedimentaryvolcanic plutonic belt; (2) Late Carboniferous and Early Permian Hangay plutonic belt; and (3) Jurassic and Early Cretaceous Uda-Murgal and Stanovoy granite belts; (4) Devonian to Triassic Lan continental-margin turbidite terrane; and (2) Late Triassic to Middle Jurassic Ulban continental-margin turbidite terrane.

Tectonically linked to the arc are the following subduction zone terranes: (1) Cambrian to Early Carboniferous Galam terrane (GL); (2) Silurian to Permian Tukuringra-Dzhagdy terrane; (3) Silurian to Late Carboniferous Hangay-Dauria terrane; and (4) Paleozoic Ononsky terrane.

The collage formed during long-lived closure of MongolOkhotsk Ocean with oblique subduction of terranes beneath the southern North Asian Craton Margin and previouslyaccreted terranes. Closure and accretion extend from the Permian to the Late Jurassic (140 to 90 Ma). After closure of the Mongol-Okhotsk Ocean, left-lateral slip continued along the Mongol-Okhotsk fault that bounded the former ocean and resulted in formation of Trans-Baikalian-Daxinganling bimodal igneous belt.

SL - Solon collage (Carboniferous to Permian; Timing of accretion - Late Paleozoic to Early Mesozoic). Consists of following subduction zone terranes: (1) Carboniferous and Early Permian North Margin terrane; (2) Late Carboniferous to Permian Solon terrane; (3) Devonian Imjingang terrane; (4) Paleozoic Ogcheon terrane; and (5) Silurian through Permian Sangun-Hidagaien-Kurosegawa terrane. The terranes of the collage are fragments of Solon Ocean plate. The terranes locally contain sedimentary units with mixed Tethyan and Boreal fossils.

The subduction zone terranes were derived from underthrusting of the northern part of the Solon Ocean plate to form a continental-margin arc on the South MongoliaKhingan collage and Argun-Idermeg superterrane (Amur microcontinent composed of Agun and Idermeg passive continental margin terranes). The arcs are: (1) South Mongolian arc composed of Middle Carboniferous to Late Triassic South Mongolian volcanic-plutonic belt; (2) Lugyngol arc composed of Permian Lugyngol volcanic and sedimentary basin; (3) Gobi-Khankaisk-Daxing'anling arc composed of Permian Gobi-Khankaisk-Daxing'anling volcanicplutonic belt; and (4) Jihei arc composed of Permian Jihei plutonic belt.

Various subduction zone terranes were derived from underthrusting of the southern part of Solon Ocean plate and are tectonically linked to the North Margin continental-margin arc that formed on the Sino-Korean Craton. The arc is composed of the Carboniferous and Permian North Marginal Plutonic Belt of North China Platform.

The various terranes in the Solon collage were accreted to continental margins in the Permian to Triassic (290 to $203 \mathrm{Ma})$.

SM - South Mongolia-Khingan collage (Ordovician to Carboniferous; Timing of accretion - Late Carboniferous or Early Permian). Major unit in collage is the South MongoliaKhingan arc and tectonically-linked subduction zone terranes.

Collage consists mainly of extensive local Ordovician, Silurian, Devonian, and Mississippian island arc and turbidite terranes and tectonically-linked subduction zone terranes. Preserved in various fragments in the: (1) Neoproterozoic through Early Carboniferous Nora-SukhotinDuobaoshan island arc terrane; (2) Devonian to Carboniferous Beitianshan-Atasbogd terrane; (3) Cambrian to Middle 
Devonian Dongwuzhumuqin-Nuhetdavaa terrane; (4) Middle Ordovician to Early Carboniferous Mandalovoo-Onor terrane; (5) Silurian to Early Carboniferous Gurvansayhan terrane; (6) Devonian and Early Carboniferous Edren terrane; (7) Cambrian to Devonian Govi Altai turbidite terrane; (8) Ordovician to Devonian Bayanleg subduction zone terrane; and (8) Devonian to Permian Hegenshan terrane. The tectonically-linked subduction zone terranes are: (1) Ordovician(?) and Devonian Zoolen terrane; and (2) Devonian Mandan terrane.

The South Mongolia-Khingan island arc was separated from the North Asian Craton by a large back-arc basin now represented in fragments contained in the: (1) Ordovician to Devonian Bayanleg subduction zone terrane; and (2) Devonian Mandah subduction zone terrane. The collages comprising the arcs were accreted to the southern margin of the Siberian continent in the Late Carboniferous or Early Permian (320 to $300 \mathrm{Ma}$ ).

WD - Wundurmiao collage (Mesoproterozoic to Silurian; Timing of accretion - Late Silurian). Consists of: (1) Late Ordovician to Silurian Laoling island arc terrane; (2) Mesoproterozoic to Middle Ordovician Wundurmiao subduction zone terrane; and (3) Neoproterozoic Seluohe subduction zone terrane. The collage consists of the Laoling island arc system that formed near Sino-Korean Craton that was widely separated from North Asian Craton in the Early Paleozoic. The collage intruded by granodiorite with a U-Pb age of $466 \mathrm{Ma}$ and unconformably overlain by Silurian clastic rock. The collage was accreted to the Sino-Korean Craton in the Late Silurian (435-415 Ma) along a transform continental margin.

The timing of the accretion of the collage to the Siberian continent is constrained by an angular unconformity at the base of the Upper Silurian or Devonian units and by orogenic granitoid magmatism of Early Devonian or older (preEmsian) age (about 435-415 Ma).

WS - West Siberian collage (Ordovician to Carboniferous Timing of accretion - Late Carboniferous or Early Permian). Preserved in various fragments in Southwestern Siberia. Consists of the: (1) Late Silurian to Early Carboniferous Rudny Altai island arc terrane; and (2) the tectonicallylinked Ordovician to Early Carboniferous Kalba-Narim subduction zone terrane. The collage is a northwest continuation (present-day coordinates) of the South Mongolia-Khingan island arc. The collage extends under Cenozoic and Mesozoic cover of Southwestern Siberia.

YT - Yenisey-Transbaikal collage (Vendian to Devonian; Timing of accretion - Vendian to Early Ordovician). Consists of Vendian to Middle Cambrian Kuznetsk-Tannuola, Dzhida-Lake island arc terranes, tectonically-linked backarc basins, and tectonically eroded subduction zone terranes. The collage consists of a linear array of Vendian and Cambrian island arc systems that formed south (present-day coordinates) of the North Asian Craton and Margin and previously accreted terranes.
The collage is unconformably overlain by OrdovicianSilurian flysch and molasse and also contains local Early Ordovician metamorphic and granitoid complexes. Accretion of the collage to the Siberian continent occurred in the Late Cambrian to Early Ordovician (500 to $460 \mathrm{Ma}$ ) during counter-clockwise rotation of the Siberian continent that resulted in collision and duplexing of island arcs, and closure of the back-arc basins. As a result, most of the island arcs and tectonically-linked subduction zones ceased activity in Middle Cambrian. In Late Cambrian and Early Ordovician, collisional granitoid batholiths were emplaced and along with high-temperature metamorphic belts.

Kuznetsk-Tannuola island arc (Vendian to Middle Devonian). Preserved in various fragments in Southern Siberia and Mongolia in the: (1) Neoproterozoic to Devonian TelbesKitat island-arc terrane; (2) Late Neoproterozoic and Cambrian Kozhukhov island arc terrane; (3) Late Neoproterozoic and Early Cambrian Kanim island arc terrane; (4) Cambrian to Ordovician Uimen-Lebed island arc terrane; (5) Early Cambrian Kurai island arc terrane; (6) Neoproterozoic to Devonian Ulgey Island arc terrane; (7) Neoproterozoic to Early Cambrian North Sayan island arc terrane; (8) Cambrian Kizir-Kazir island arc terrane; (9) Cambrian Khamsara island arc terrane; (10) Early Cambrian Ulugo island arc terrane; (11) Late Neoproterozoic to Ordovician Ondum island arc terrane; (12) Cambrian and older(?) Tannuola island arc terrane; and (13) Late Riphean to Middle Cambrian Minusinsk back-arc basin.

The tectonically-linked subduction zone, subduction zone, and oceanic crust units are the: (1) Late Neoproterozoic Teletsk subduction zone terrane; (2) Late Neoproterozoic and Early Cambrian Dzhebash subduction zone terrane; (3) Vendian and Early Cambrian Alambai subduction zone terrane; (4) Early Cambrian Borus subduction zone terrane; and (5) Late Neoproterozoic and Early Cambrian Kurtushiba subduction zone terrane. Blueschist facies units occur in the Borus and Kurtushiba terranes.

Behind the Kuznetsk-Tannuola island arc was the Minusa and Tuva molasse units in the Altai-Sayan and East Tuva back-arc basins. The units in the Altai-Sayan back-arc basin are the: (1) Late Neoproterozoic and Cambrian Biya-Katun unit; (2) Late Neoproterozoic and Cambrian Kiya unit; and (3) Late Neoproterozoic Kizhikhem unit. The East Tuva back-arc basin is Late Neoproterozoic and Cambrian age. The Minusa and Tuva back-arc molasse basins represent superposed structures related to the formation of Hercynian ocean basins.

Dzhida-Lake island arc (Vendian to Middle Cambrian). Preserved in various fragments in Southern Siberia and Mongolia in the: (1) Late Neoproterozoic and Cambrian Lake island arc terrane; (2) Late Neoproterozoic and Early Cambrian Eravna island arc terrane; (3) Late Neoproterozoic to Silurian Orhon-Ikatsky arc terrane; and (4) Late Neoproterozoic and Early Cambrian Dzhida island arc terrane. 
Behind the Dzhida-Lake island arc was the Transbaikal back arc basin that consists of the: (1) the Ikatsky part of the Late Neoproterozoic to Silurian Orhon-Ikatsky continentalmargin arc terrane; (2) part of the Paleoproterozoic through Early Cambrian Hamar-Davaa metamorphic terrane; and (3) part of the Late Neoproterozoic Barguzin metamorphic terrane.

\section{A7 Tectonic collages accreted onto Eastern Margin of North Asian and Sino-Korean Cratons (Mesozoic and Cenozoic accretions)}

BD - Badzhal collage (Triassic to Early Cretaceous; Timing of accretion - Late Cretaceous). Consists of subduction zone terranes composed of mainly Triassic and Jurassic turbidite with fragments of Pennsylvanian and Permian limestone and chert containing Tethyan fauna, Late Triassic and Jurassic chert, and small basalt lenses. Preserved in fragments of the following terranes in the northern Russian Southeast: (1) Triassic to Middle Jurassic Badzhal subduction zone terrane; and (2) Middle Triassic through Middle Jurassic Nadanhada subduction zone terrane.

The subduction zone terranes were subducted beneath the Siberian continental margin and previously-accreted terranes, thereby resulting in formation of the Umlekan continental-margin arc that is composed of the Cretaceous Umlekan-Ogodzhin volcanic-plutonic belt. The collage was amalgamated and accreted to the Siberian continental margin during subsequent strike-slip emplacement of outboard terranes in the Early Cretaceous. The collage is unconformably overlain by the Late Albian and Late Cretaceous Okhotsk-Chukotka volcanic-plutonic belt that forms a major continental-margin arc.

$\mathrm{CH}$ - Chukotka collage (Paleozoic to Triassic; Timing of accretion - Late Jurassic to Early Cretaceous). Consists of passive continental-margin terranes that formed along the long-lived Neoproterozoic to Early Mesozoic North American Continental Margin. Major units are Paleozoic to Triassic continental shelf and slope sedimentary rock, Early Jurassic flysch, and unconformably overlying, flat-lying Late Jurassic and Early Cretaceous sedimentary overlap units. The collage consists of various passive continental margin terranes that originally formed along the North American Craton Margin. The collage formed during rifting of the North American Craton Margin in the Late Jurassic and Early Cretaceous and accretion of terranes to northern the North Asian Craton Margin in the Late Cretaceous.

EP - East Kamchatka Peninsula collage (mainly Paleocene; Timing of accretion - Pliocene). Consists of Coniacian-Paleocene island arc formations with ophiolite fragments that are preserved mainly in the: (1) Late Cretaceous to Paleocene Kronotskiy island arc terrane; and (2) mainly Cretaceous and Paleocene Kamchatskiy Mys oceanic terrane. The collage is a short-lived island arc and adjacent oceanic crust that were accreted to the Eastern Asia continental margin during closure of an inboard ocean in the Pliocene. The collage is unconformably overlain by flatlying Quaternary volcanic units.

ES - East Sakhalin collage (Late Cretaceous to Early Tertiary; Timing of accretion - Early Tertiary). Consists of Late Cretaceous to Middle Eocene island arc and tectonicallylinked subduction zone terranes in fragments in the: (1) Late Cretaceous Terpeniy island arc terrane; (2) Late Cretaceous to Middle Eocene Tokoro-Nemuro island arc terrane; (3) Late Jurassic through Late Cretaceous Shmidt island arc terrane; (4) Early Cretaceous to Miocene Shimanto subduction zone terrane; and (5) probable subduction zone terranes delineated by linear positive magnetic anomalies to the east of Sakhalin Island. Accretion of the island arc to the Eastern Asia continental margin occurred during closure of an inboard ocean and resulted in formation of collision-related granitoids at about $40 \mathrm{Ma}$.

HS - Honshu-Sikhote-Alin collage (Jurassic and Early Cretaceous; Timing of accretion - Cretaceous). Consists of fragments of subduction zone, continental-margin turbidite (flysch), and island arc terranes. Preserved in fragments are the: (1) Permian to Early Cretaceous Mino Tamba Chichibu subduction zone terrane; (2) Carboniferous and Permian Akiyoshi-Maizuru subduction zone terrane containing fragments of sedimentary units with Tethyan fossils; (3) Cretaceous Sambagawa metamorphic terrane; (4) Late Early Cretaceous Kema island arc terrane; (5) Late Jurassic through Early Cretaceous Taukha subduction zone terrane; (6) Late Permian through Middle Jurassic Samarka subduction zone terrane; (7) Early Paleozoic (?) Khor island arc terrane; (8) Jurassic and Early Cretaceous Kiselyovka-Manoma subduction zone terrane; and (9) Late Jurassic and Early Cretaceous Zhuravlevsk-Amur River continental-margin turbidite terrane. The Zhuravlevsk-Amur River continental-margin turbidite terrane and companion island arc terranes that formed along a Late Jurassic and Early Cretaceous continentalmargin transform fault along which the older Mino Tamba Chichibu subduction zone and Akiyoshi-Maizuru subduction zone terranes were emplaced. The collage formed along a transform continental margin. The collage is unconformably overlain by Late Albian and younger flat-lying volcanic units of the East Sikhote-Alin volcanic-plutonic belt and its continuation onto Honshu Island.

KOR - Koryak collage (Late Triassic to Cretaceous; Timing of accretion - Late Cretaceous). Consists of a Late Jurassic and Early Cretaceous island arc and tectonically-linked subduction zone terranes that are preserved in fragments are the: (1) Late Jurassic to Mid-Cretaceous Mainitskiy island arc terrane; (2) Late Jurassic to Paleocene Alkatvaam subduction zone terrane; (3) Paleozoic Zolotogorskiy passive continental margin terrane; and (4) Upper Paleozoic-Early Cretaceous Ekonay subduction zone terrane.

OK - Olyutorka-Kamchatka collage (Late Cretaceous and Paleocene; Timing of accretion - Early Cenozoic). Consists of island arc and tectonically-linked subduction zone terranes 
in fragments in the: (1) Late Early Cretaceous to Paleocene Olyutorka-Kamchatka island arc terrane; (2) Late Cretaceous Iruneiskiy island arc terrane; and (3) Late Cretaceous to Oligocene Vetlovskiy subduction zone terrane. The collage is unconformably overlain by Late Eocene, Oligocene, and Miocene sedimentary units. The collage was accreted to the Eastern Asia continental margin during closure of inboard ocean.

PA - Penzhina-Anadyr collage (Late Jurassic to Early Cretaceous; Timing of accretion - Late Cretaceous). Consists of Late Jurassic-Neocomian subduction zone terranes and a tectonically-linked island arc terrane that rim the eastern Kolyma-Omolon superterrane and Verkhoyansk-Kolyma collage. Preserved in fragments are the: (1) Ordovician to Middle Jurassic Penzhina Anadyr subduction zone terrane that includes fragments of Devonian ophiolite; (2) Middle and Late Jurassic Talovskiy subduction zone terrane; (3) the Late Triassic to Early Cretaceous Kony-Murgal arc terrane; (4) Triassic Velmay subduction zone terrane; and (5) West Pekulney island arc terrane. The subduction zone terranes were subducted beneath the margin of the Siberian continent margin and previously-accreted terranes to form the Uda-Murgal continental-margin arc and offshore extension into the Kony-Murgal island arc. The collage was formed in the Senomanian-Campanian following the closure of the outboard Mongol-Okhotsk Ocean. The collage consists of the Uda-Murgal continental-margin and island arc and and tectonically-linked subduction zone terranes. The collage is unconformably overlain by the Late Albian and Late Cretaceous Okhotsk-Chukotka volcanic-plutonic belt (oc) that forms a major continental-margin arc.

SA - South Anyui collage (Permian to Early Jurassic; Timing of accretion - Late Cretaceous). Consists of Late Jurassic to Neocomian subduction zone terranes, and island and continental-margin arc terranes that rim the northeastern Kolyma-Omolon superterrane and Verkhoyansk-Kolyma collage. Preserved in fragments are the: (1) mainly Late Jurassic-Early Cretaceous South Anyui subduction-zone terrane; (2) Triassic and Early Jurassic Velmay subduction-zone terrane; (3) Late Jurassic and Early Cretaceous Oloy and Late Jurassic Svyatov Nos volcanic belts along the northeast margin of the Kolyma-Omolon superterrane; (4) and Late Jurassic and Early Cretaceous Nutesyn continental-margin arc terrane that formed on the margin of the Chukotka collage during the closure of the South Anyui Ocean; (5) Permian and Triassic Shalaurov subduction zone terrane. The collage consists of the Oloy island arc and tectonically-linked subduction zone terranes. The collage was accreted onto the Siberian continent margin during closure of the South Anyui Ocean in the Early Late Cretaceous. The collage is unconformably overlain by the Late Albian and Late Cretaceous Okhotsk-Chukotka volcanic-plutonic belt (oc) that forms a major continental-margin arc.

The collage is unconformably overlain by Maastrichtian, Eocene and Oligocene sedimentary and volcaniclastic rock.
The accretion of collage to the Russian Northeast continental margin occurred during closure of the inboard ocean and was followed by formation of the Okhotsk-Chukotka continental-margin arc and tectonically-linked outboard subduction zone.

SH - Sakhalin-Hokkaido collage (Cretaceous; Timing of accretion - Eocene). Consists of Late Cretaceous flysch terranes of Sakhalin and Hokkaido Islands, and tectonicallylinked subduction zone terranes to the east that contain fragments of ophiolite, glaucophane schist, Late Jurassic and Early Cretaceous limestone with Tethyan reef corals and island arc terrane. Preserved in fragments are the: (1) Middle Triassic to Early Late Cretaceous Aniva subduction zone terrane; (2) Jurassic to Paleogene Sosunay-Langeri subduction zone terrane; (3) Early Cretaceous to Miocene Shimanto subduction zone terrane; (4) Late Cretaceous through Paleogene Nabilsky subduction zone terrane; and (5) Late Jurassic through Late Cretaceous Kamyshovy island arc terrane. The terranes were subducted beneath the Eastern Asia continental margin resulting in the formation of the East-SikhoteAlin continental-margin arc composed of the: (1) Late Cretaceous to Miocene East Sikhote-Alin volcanic-plutonic belt; and (2) Early Cretaceous West Sakhalin turbidite basin terrane. The collage was a continental-margin fore-arc basin and tectonically-linked subduction zone terranes associated with the East Sikhote-Alin continental-margin arc. Accretion of the collage to the Russian Southeast continental margin occurred during closure of the inboard ocean and was followed by formation of outboard modern-day continentalmargin arcs in Russian Northeast, Kurile Islands, and Japan and tectonically-linked outboard subduction zone.

VK - Verkhoyansk-Kolyma collage (Late Paleozoic to Early Jurassic; Timing of accretion - Late Jurassic to Early Early Cretaceous). Consists of: (1) Permian, Triassic, and Early Jurassic Kular-Nera passive continental margin terrane $(\mathrm{KN})$ that formed between the North Asian Craton Margin and the Kolyma-Omolon superterrane to the east in the Russian Northeast; The rocks of the terrane are distal formations of the Verkhoyansk passive continental margin; (2) Mid-Late Jurassic Polousny-Debin subduction zone terrane; (3) Carboniferous to Jurassic Viliga passive continental-margin terrane; (4) Debin ophiolite terrane; and (5) Late Neoproterozoic through Late Triassic Kotel'nyi passive continental margin terrane. Part of Kular-Nera terrane was subducted beneath the Kolyma-Omolon superterrane in the Late Jurassic resulting in formation of the Late Jurassic Uyandina-Yasachnaya island arc along the southern margin of the Kolyma-Omolon superterrane. Ophiolite terranes (Garbyn'ya, Indigirka, Kybytygas, Munilkan, and Uyhandina) derived from the collapsing ocean basin were obducted onto the superterrane. The Polousny-Debin subduction zone formed during subduction of the Oimyakon oceanic crust beneath the southern margin of the KolymaOmolon superterrane. Consists of a deformed passive continental margin, accreted ophiolites, and subduction zone 
and formed during accretion of outboard Kolyma-Omolon superterrane.

WK - West Kamchatka collage (Mid-Cretaceous to Early Tertiary; Timing of accretion - Early Cenozoic). Consists of Late Paleozoic to Cretaceous subduction zone terranes in the Russian Northeast in the: (1) Jurassic and Cretaceous West Kamchatka subduction zone terrane; (2) Late Jurassic and Cretaceous Yanranay subduction zone terrane; and (3) Jurassic Ekonay subduction zone terrane.

The collage is tectonically linked to Okhotsk-Chukotka continental-margin arc (Mid-Cretaceous to Early Tertiary, 96-50 Ma) that consists of the: (1) Mid-Cretaceous to Early Tertiary Okhotsk-Chukotka volcanic-plutonic belt; and (2) Albian and Late Cretaceous Penzhina sedimentary basin. The collage was accreted to the Eastern Asian continental margin during outboard accretion of the OlyutokaKamchatka island arc.

\section{A8 Overlapping continental-margin arcs - Devonian to Early Tertiary}

at - Altay arc (Devonian and Early Carboniferous, 381 to 290 Ma). Occurs in Southwestern Siberia, Northwestern Mongolia, and Western Northern China. It consists of an extensive suite of mafic and intermediate, and local siliceous volcanic rock, mafic and intermediate intrusive rock, and associated sedimentary rock; stratified units deposited under continental to marine conditions; igneous rocks range from calc-alkaline to subalkaline to alkaline. The arc formed along an active continental margin in an oblique subduction zone environment.

ea - East Sikhote-Alin arc (Late Cretaceous to Early Tertiary, 96 to $55 \mathrm{Ma}$ ). Occurs along the margin of the Southern Russian Far East and consists of Late Cretaceous and Early Tertiary volcanic and plutonic rocks in the East Sikhote-Alin and West Sakhalin turbidite-basin terranes. The arc formed during subduction of the Ancestral Pacific Ocean plate with formation of the older part of the Hidaka subduction zone, the younger part of the Aniva subduction-zone terrane, and the Nabilsky, and Tokoro subduction-zone terranes.

gh - Gobi-Khankaisk-Daxing' anling arc (Permian, 295 to $250 \mathrm{Ma}$ ). Occurs in Northern China, Mongolia, and Transbaikal Region and consists of Gobi-KhankaiskDaxing'anling volcanic-plutonic belt that overlies and intrudes the Argun-Idermeg superterrane; the South Mongolian collage, and Solon Collage; volcanic and related sedimentary units composed of basalt, andesite, dacite, rhyolite, tuff, sandstone, siltstone, conglomerate, sandstone, and minor limestone; granitoid units composed of adamellite, granite, granodiorite, monzonite granite, quartz monzonite, quartz diorite, gneissic granite, and two-mica granite. The arc formed during subduction of the northern part of Solon Ocean plate under the southern margin (present-day coordinates) of the Argun-Idermeg superterrane. ha - Hangay arc (Late Carboniferous to Early Permian, 320 to $272 \mathrm{Ma}$ ). Occurs in Central Mongolia and consists of large- to medium-size multiphase intrusions composed of granodiorite, tonalite, plagioclase granite, and minor gabbrodiorite, diorite, quartz diorite, and plagioclase leucogranite. These intrude the Yenisey-Transbaikal collage and MongolOkhotsk collage. The arc formed during subduction of the northern part of Mongol-Okhotsk Ocean plate under the North Asian Craton Margin and previously-accreted terranes.

ji - Jihei arc (Permian, 295-250 Ma). Occurs in Eastern China and consists of granodiorite, monzonite, quartz diorite, quartz monzonite, diorite, syenite, and akali-feldspar granite. Unit intrudes Bureya-Jiamusi supterterrane and South Mongolia-Khingan collage. The arc formed during subduction of the northern part of Solon Ocean plate under the southern margin (present-day coordinates) of the BureyaJiamusi supterterrane and adjacent units.

ko - Khingan-Okhotsk arc (Early and Mid-Cretaceous). Occurs in the Russian Southeast and consists of the KhinganOkhotsk volcanic-plutonic belt that contains K-rich felsic volcanic rocks and coeval subvolcanic to plutonic granitioids. The arc was tectonically paired to the Early Cretaceous Zhuravlevsk-Amur River and Kiselevka-Manoma subduction-zone terranes, part of the Honshu-Sikhote-Alin collage.

$\lg$ - Lugyngol arc (Permian, 295 to $250 \mathrm{Ma}$ ). Occurs in Southeastern Mongolia and consists of Lugyngol volcanic and sedimentary basin composed of calk-alkalic andesite, dacite, rhyolite, conglomerate, sandstone, siltstone, and extensive flysch. Unit overlies and intrudes the South Mongolian collage and Solon collage. The arc formed during subduction of the northern part of Solon Ocean plate under the southern margin (present-day coordinates) of the ArgunIdermeg superterrane.

ma - Main Granite Belt (Late Jurassic, 144 to $134 \mathrm{Ma}$ ). Occurs along adjacent margins of the North Asian Craton Margin and Kolyma-Omolon superterrane. Consists of Main amphibole-biotite granite, two mica granite, and granodiorite. The Granite Belt formed during and immediately after collision of the Kolyma-Omolon superterrane onto the North-Asian Craton Margin.

nb - Northern Granite Belt (Early Cretaceous, 138 to $120 \mathrm{Ma})$. Occurs along northwestern margin of the KolymaOmolon superterrane. Consists of large, elongated plutons composed of quartz diorite, monzodiorite, and biotite granite, as well as amphibole-biotite granodiorite, biotite granite, and two-mica granite. The belt formed during subduction of oceanic crust during a closure of a small oceanic basin during late stage of accretion of Kolyma-Omolon superterrane.

$\mathrm{nm}$ - North Margin arc (Late Carboniferous to Permian, 320 to $272 \mathrm{Ma}$ ). Occurs in Northern China and consists of north marginal plutonic belt composed of calc-alkalic granodiorite, quartz monzonite, and granite. Unit intrudes northeastern margin (present-day coordinates) of Sino-Korean Craton. The arc formed during subduction of the southern 
part of Solon Ocean plate under the northeastern margin (present-day coordinates) of Sino-Korean Craton.

$\mathrm{nr}$ - Norovlin arc (Devonian to Early Carboniferous). Occurs in Northern Mongolia and the Transbaikal region and consists of a continental-margin arc formed on the ArgunIdermeg superterrane (Amur microcontinent - Argunsky and Idermeg passive continental margin terranes). The arc is preserved in Early to Middle Devonian calc-alkaline volcanic rock and in Middle to Late Devonian volcaniclastic rock, chert, and mudstone, and coeval granitoids that overlie or intrude the superterrane, and in Devonian to Early Carboniferous volcanic-sedimentary rock fragments in the Ononsky subduction zone terrane. The arc formed during subduction of the Mongol-Okhotsk Ocean plate beneath northern margin (present-day coordinates) of Argun-Idemeg superterrane (Amur microcontinent).

oc - Okhotsk-Chukotka arc (Late Cretaceous to Early Tertiary, 96 to $53 \mathrm{Ma}$ ). Occurs along the margin of the Central and Northern Russian Far East and consists of Mid- and Late Cretaceous and Early Tertiary volcanic and plutonic units in the Okhotsk-Chukotka volcanic-plutonic belt (oc) and the Penzhina sedimentary basin. The arc formed during subduction of the Ancestral Pacific Ocean plate with formation of West Kamchatka, Ekonay, and Yanranay subduction zone terranes.

ol - Oloy arc (Late Jurassic, 154 to $135 \mathrm{Ma}$ ). Occurs along the margin of the Kolyma-Omolon superterrane and consists of Late Jurassic-Neocomian Oloy volcanic belt, Late Jurassic Svyatov Nos volcanic belt, and the Indigirka-Oloy sedimentary-volcanic-plutonic assemblage. The arc was an island arc that formed on Kolyma-Omolon superterrane during subduction of the South Anyui Ocean plate beneath superterrane and formation of South Anyui subduction-zone terrane.

se - Selenga arc (Permian to Jurassic, 295 to $135 \mathrm{Ma}$ ). Occurs in Mongolia and southern Transbaikal regions and consists of large volcanic fields and granite plutons. Volcanic rock composed of rhyolite, trachyrhyolite, dacite, trachydacite, andesite basalt, trachybasalt, and andesite flows, and pyroclastic rocks, and local non-marine sedimentary rocks. Granite plutons composed of granodiorite, granite, granosyenite, and subordinate monzonite, diorite, and gabbrodiorite, REE granite, and leucogranite. Unit overlies and intrudes Yenisey-Transbaikal collage and Tuva-Mongolia superterrane. The arc formed during oblique subduction of the Mongol-Okhotsk Ocean plate under the North Asian Craton Margin and previously-accreted terranes.

sm - South Mongolian arc (Middle Carboniferous through Triassic, 320 to 203 Ma). Occurs in Southern Mongolia and consists of South Mongolian volcanic-plutonic belt composed of calc-alkalic basalt, andesite, basaltic andesite, dacite, and rhyolite, and interbedded tuff and tuffaceous sandstone, granodiorite, granite, and leucogranite. Unit overlies and intrudes South Mongolian collage and Atasbogd collage. The arc formed during subduction of northern part of Solon ocean under the Argun-Idermeg superterrane.

sv - South Verkhoyansk Granite Belt (Late Jurassic to Mid-Cretaceous, 157 to $93 \mathrm{Ma}$ ). Occurs in the Central Russian Far East. Extends longitudinally along the central part of the South Verkhoyansk synclinorium in the Verkoyansk (North Asian) Craton Margin. Occurs as batholiths, smaller granitoid plutons, and dikes. Compositions include amphibole-biotite quartz diorite and granodiorite, adamellite, amphibole-biotite granite, local melanocratic syenodiorite, and local dikes of plagiogranite and granite aplite, leucocratic biotite granite, and pegmatite lamprophyre. Granitoids are mainly high-K calc-alkaline series, subaluminous, and highly ferruginous. The Granite Belt formed during the accretion of the outboard Okhotsk terrane.

tv - Transverse Granite Belt (Early Cretaceous, 134 to $124 \mathrm{Ma})$. Consists of several belts of granitic rocks that extend up to a few hundred $\mathrm{km}$ and radiate outwards from the southwestern bend of the Kolyma-Omolon superterrane. The belts taper out to the southwest and north and consists of fracture-related plutons and dikes swarms composed mainly of diorite, granodiorite, and granite. The belts crosscut, at high angle, older folds and faults of the Verkhoyansk (North Asian) Craton Margin. The belt formed during the late-stage of accretion of Kolyma-Omolon superterrane.

uo - Umlekan-Ogodzhin arc (Jurassic and Cretaceous, 135 to $65 \mathrm{Ma}$ ). Occurs along the margin of the Kolyma-Omkolon superterrane and consists of Umlekan-Ogodzhin volcanicplutonic belt and coeval Late Jurassic and Early Cretaceous granitic plutons. Tectonically linked to the Badzhal and Nadanhada subduction-zone terranes, part of the Badzhal collage.

us - Uda-Murgal and Stanovoy arcs (Jurassic to Early Cretaceous, 203 to $96 \mathrm{Ma}$ ). Occurs in central part of the Russian Far East and consists of Late Jurassic and Early Cretaceous, and lesser Late Triassic to Middle Jurassic igneous-rock preserved in the Uda volcanic-plutonic belt, the Uniya-Bom turbidite-basin terrane, the Umlekan-Ogodzhin volcanic-plutonic belt, the Upper Amur sedimentary assemblage, and the Stanovoy Granite Belt. The arc intrudes and overlies southern margin of the North Asian Craton. The arc formed during subduction of the Mongol-Okhotsk Ocean plate and formation of the Tukuringra-Dzhagdi subductionzone, Galam subduction zone, and Ulban subduction zone terranes.

uy - Uyandina-Yasachnaya arc (Late Jurassic to Early Cretaceous, 154 to $120 \mathrm{Ma}$ ). Occurs along the southern margin of the Kolyma-Omkolon superterrane and consists of the Uyandina-Yasachnaya volcanic belt, Zyryanka sedimentary basin, the small Ainakhkurgen, Umkuveem, and Upper Penzhina basins, and the North Omolon basin that form part of the Indigirka-Oloy sedimentary-volcanic-plutonic assemblage. The arc formed during subduction the Oimyakon Ocean plate between the North Asian Craton Margin and the Kolyma-Omolon superterrane. Remnants of oceanic crust 
are preserved in small obducted ophiolites along the margin of superterrane.

\section{A9 Transpressional arcs - Devonian to Early Cretaceous}

mt - Mongol-Transbaikal arc (Late Triassic to Early Cretaceous, 230 to $96 \mathrm{Ma}$ ). Occurs in Northern Mongolia and southern Transbaikal regions. Preserved in the Late Triassic to Early Cretaceous Mongol-Transbaikal region volcanic-plutonic belt $(\mathrm{mt})$ that consists of volcanic rocks in separate major basins and composed of trachyandesite, dacite, and trachyrhyolite flows, stocks, necks, and extrusive domes. The Mongol-Transbaikal arc also includes coeval granite plutons composed of grandiorite, alkaline gabbrogranite, granite, leucogranite, and Lithiumn-Fluorine rich granite. The arc formed during strike-slip faulting and rifting along the Mongol-Okhotsk fault during and after the final closure of the Mongol-Okhotsk Ocean. The arc is also referred to as North Gobi arc.

ss - South Siberian arc (Early Devonian, 415 to $400 \mathrm{Ma}$ ). Occurs in Eastern Altai-Sayan region and consists of South Siberian volcanic-plutonic belt, involving volcanic rocks composed of bimodal mafic and siliceous volcanic rock including andesite, olivine basalt, trachybasalt, essexite, phonolite, alkaline trachite, trachyandesite, and trachyrhyolite. Plutonic rocks are composed of subalkaline to alkaline gabbro to granite, alkaline-syenite, granosyenite, leucogranite, and latite-bearing subalkaline gabbro, monzonite, and syenogranite. The arc formed along the southern margin of the North Asian Craton and Craton Margin during Early Devonian rifting that successively evolved into a continentalmargin transpressive-fault margin and into a convergent margin.

tr - Trans-Baikal-Daxinganling arc (Middle Jurassic through Early Cretaceous, 175 to $96 \mathrm{Ma}$ ). Occurs in Transbaikal region, Mongolia, Northeastern China and consists of Trans-Baikalian-Daxinganling sedimentaryvolcanic-plutonic belt. Volcanic rocks are composed of shoshonite, latite, trachyte, trachyandesite, trachybasalt, trachyrhyolite, latite subalkaline basalt, and basalt andesite. Plutonic rocks are composed of large calc-alkaline to subalkaline plutons of granite, leucogranite, quartz syenite, quartz monzonite, granodiorite, and biotite-amphibole diorite, and small calc-alkaline subvolcanic bodies of dacite and rhyolite. The arc formed during strike-slip faulting and rifting along the Mongol-Okhotsk fault during, and after the final closure of the Mongol-Okhotsk Ocean.

\section{A10 Active continental-margin arcs - Miocene to Present}

ib - Izu-Bonin arc (Miocene through Present, 20 to $0 \mathrm{Ma}$ ). Occurs in the south of Southern Japan and consists of a volcanic arc composed chiefly of basalt to rhyolite, associated volcaniclastic rocks, and intercalated hemipelagic mudstone. The arc formed during subduction of the Philippine Sea Plate with formation of Nankai subduction zone.

ja - Japan arc (Miocene through Present, 23 to $0 \mathrm{Ma}$ ). Occurs along the Japanese Islands and consists of extensive Quaternary volcanic rock formed during subduction of the Pacific and Philippine Sea Plates. Also contains associated volcanogenic forearc and back arc sedimentary basins. Volcanic rocks are mainly calc-alkaline basalt and andesite. Belt includes 83 active volcanoes and overlies all Japan terranes. The arc formed during subduction of the Pacific Ocean and Philippine Sea Plates with formaton of Japan Trench and Nankai subduction zones.

kk - Kuril-Kamchatka arc (Miocene through Present, 11 to $0 \mathrm{Ma}$ ). Occurs along Kamchatka Peninsula and Kuril Islands and consists of the Pliocene to Quaternary Central Kamchatka volcanic belt, Central Kamchatka volcanic and sedimentary basin, and the East Kamchatka volcanic belt. The arc formed during subduction of the Pacific Ocean Plate with formation of the Japan Trench subduction zone.

\section{A11 Active subduction zones - Miocene to Present}

JT - Japan Trench subduction zone (Miocene through Present; Timing of accretion -23 to $0 \mathrm{Ma}$ ). Consists of Late Tertiary and Quaternary Japan and Kuril-Kamchatka trench subduction zone terranes. Tectonically linked to the: (1) Miocene to Present Japan arc (ja); (2) Miocene to Present Kuril-Kamchatka arc; and (3) Paleogene through Quaternary Japan and Izu-Bonin forearc basins. The subduction formed during active underthrusting of the Western Pacific Ocean Plate beneath the Eastern Asia continental margin.

NN - Nankai subduction zone (Miocene through Present; Timing of accretion -23 to $0 \mathrm{Ma}$ ). Consists of the Miocene through Quaternary Nankai subduction zone terrane. Tectonically linked to the: Miocene to Present Japan arc; (2) Miocene to Present Izu-Bonin volcanic belt; (3) Paleocene Kyushu-Palau island arc terrane; and (4) Miocene through Quaternary Izu-Bonin island arc terrane. The subduction formed during active underthrusting of a fragment of the $\mathrm{Pa}$ cific Ocean Plate.

Acknowledgements. In the last three decades, many persons have assisted the authors in developing and employing the concepts of combined regional geodynamics and tectonic analysis, and in developing methods for synthesizing a tectonic model. These persons include David L. Jones, James W. H. Monger, Ian O. Norton, David W. Scholl, Christopher R. Scotese, and David B. Stone. We also thank managers N. L. Dobretsov, L. C. Gundersen, P. P. Hearn, K. Johnson, R. Koski, L. P. Leahy, J. Medlin, M. Power, and J. N. Weaver for their encouragement and support of the project. The constructive reviews of this article by Charles Cunningham, Jeremy Hourigan, and William Harbert are appreciated. 


\section{References}

Greninger, M. L., Klemperer, S. L., and Nokleberg, W. J.: Geographic information systems (GIS) compilation of geologic, geophysical, and tectonic data for the Circum-North Pacific, edited by: Nokleberg, W. J., and Diggles, M. F., US Geological Survey, Open-File Report 99-422, CD-ROM, 1999.

Howell, D. G., Jones, D. L., and Schermer, E. R.: Tectonostratigraphic terranes of the Circum-Pacific region: principles of terrane analysis, in: Tectonostratigraphic terranes of the CircumPacific Region, Circum-Pacific Council for Energy and Mineral Resources, edited by: Howell, D. G., Earth Science Series, 1, 3-31, 1985.

Jones, D. L., Howell, D. G., Coney, P. J., and Monger, J. W. H.: Recognition, character, and analysis of tectonostratigraphic terranes in western North America, in: Accretion tectonics in the Circum-Pacific regions; Proceedings of the Oji International Seminar on Accretion Tectonics, Japan, 1981, edited by: Hashimoto, M., and Uyeda, S., Advances in Earth and Planetary Sciences, Tokyo, Terra Scientific Publishing Company, 21-35, 1983.

Naumova, V. V., Miller, R. M., Mikhail, I., Patuk, M. I., Kapitanchuk, M. U., Nokleberg, W. J., Khanchuk, A. I., Parfenov, L.M., and Rodionov, S. M., with contributions from 75 others: Geographic information systems (GIS) spatial data compilation of geodynamic, tectonic, metallogenic, mineral deposit, and geophysical maps and associated descriptive data for Northeast Asia, US Geological Survey, Open-File Report 2006-1150 (CDROM), 2006.

Nokleberg, W. J., Badarch, G., Berzin, N. A., Diggles, M. F., Hwang, D. H., Khanchuk, A. I., Miller, R. J. Naumova, V. V., Obolenskiy, A. A., Ogasawara, M., Parfenov, L. M., Prokopiev. A. V., Rodionov, S. M., and Hongquan, Y. (Eds.): Digital files for Northeast Asia geodynamics, mineral deposit location, and metallogenic belt maps, stratigraphic columns, descriptions of map units, and descriptions of metallogenic belts, US Geological Survey, Open-File Report 2004-1252, CD-ROM, 2004.

Nokleberg, W. J., Bundtzen, T. K., Dawson, K. M., Eremin, R. A., Goryachev, N. A., Koch, R. D., Ratkin, V. V., Rozenblum, I. S., Shpikerman, V. I., Frolov, Y. F., Gorodinsky, M. E., Melnikov, V. D., Diggles, M. F., Ognyanov, N. V., Petrachenko, E. D., Petrachenko, R. I., Pozdeev, A. I., Ross, K. V., Wood, D. H., Grybeck, D., Khanchuk, A. I., Kovbas, L. I., Nekrasov, I. Y., and Sidorov, A. A.: Significant metalliferous lode deposits and placer districts for the Russian Far East, Alaska, and the Canadian Cordillera, US Geological Survey, Open-File Report 96-513-B, CD-ROM, 1997a.

Nokleberg, W. J., Bundtzen, T. K., Dawson, K. M., Eremin, R. A., Ratkin, V. V., Shpikerman, V. I., Goryachev, N. A., Khanchuk, A. I., Koch, R. D., Rozenblum, I. S., Gorodinsky, M. E., Frolov, Y. F., Pozdeev, A. I., Parfenov, L. M., and Sidorov, A. A.: Mineral deposit and metallogenic belt maps of the Russian Far East, Alaska, and the Canadian Cordillera, Geological Survey of Canada, Open File 3446, 2 sheets, scale 1:5000000, 5 sheets, scale 1:10000 000, 1997b.

Nokleberg, W. J., Bundtzen, T. K., Eremin, R. A., Ratkin, V. V., Dawson, K. M., Shpikerman, V. I., Goryachev, N. A., Byalobzhesky, S. G., Frolov, Y. F., Khanchuk, A. I., Koch, R. D., Monger, J. W. H., Pozdeev, A. I., Rozenblum, I. S., Rodionov, S. M.,
Parfenov, L. M., Scotese, C. R., and Sidorov, A. A.: Metallogenesis and tectonics of the Russian Far East, Alaska, and the Canadian Cordillera, US Geological Survey, Professional Paper 1697, 397 pp., 2005.

Nokleberg, W. J., Parfenov, L. M., Monger, J. W. H., Baranov, B. V., Byalobzhesky, S. G., Bundtzen, T. K., Feeney, T. D., Fujita, K., Gordey, S. P., Grantz, A., Khanchuk, A. I., Natal'in, B. A., Natapov, L. M., Norton, I. O., Patton Jr., W. W., Plafker, G., Scholl, D. W., Sokolov, S. D., Sosunov, G. M., Stone, D. B., Tabor, R. W., Tsukanov, N. V., and Vallier, T. L.: Summary Circum-North Pacific tectono-stratigraphic terrane map, US Geological Survey, Open-File Report 96-727, scale 1:10 000 000, 1997c.

Nokleberg, W. J., Parfenov, L. M., and Monger, J. W. H., Baranov, B. V., Byalobzhesky, S. G., Bundtzen, T. K., Feeney, T. D., Fujita, K., Gordey, S. P., Grantz, A., Khanchuk, A. I., Natal'in, B. A., Natapov, L. M., Norton, I. O., Patton, W. W., Jr., Plafker, G., Scholl, D. W., Sokolov, S. D., Sosunov, G. M., Stone, D. B., Tabor, R. W., Tsukanov, N. V., Vallier, T. L., and Wakita, K.: Circum-North Pacific tectono-stratigraphic terrane map, US Geological Survey,Open-File Report 94-714, 2 sheets, scale 1:5000 000, 2 sheets, scale 1:10 000 000, 211 pp., 1994.

Nokleberg, W. J., Parfenov, L. M., Monger, J. W. H., Norton, I. O., Khanchuk, A. I., Stone, D. B., Scholl, D. W., and Fujita, K.: Phanerozoic tectonic evolution of the Circum-North Pacific, US Geological Survey, Professional Paper 1626, 122 pp., 2000.

Nokleberg, W. J., West, T. D., Dawson, K. M., Shpikerman, V. I., Bundtzen, T. K., Parfenov, L. M., Monger, J. W. H., Ratkin, V. V., Baranov, B. V., Byalobzhesky, S. G., Diggles, M. F., Eremin, R. A., Fujita, K., Gordey, S. P., Gorodinskiy, M. E., Goryachev, N. A., Feeney, T. D., Frolov, Y. F., Grantz, A., Khanchuk, A. I., Koch, R. D., Natalin, B. A., Natapov, L. M., Norton, I. O., Patton, W. W. Jr., Plafker, G., Pozdeev, A. I., Rozenblum, I. S., Scholl, D. W., Sokolov, S. D., Sosunov, G. M., Stone, D. B., Tabor, R. W., Tsukanov, N. V., and Vallier, T. L.: Summary terrane, mineral deposit, and metallogenic belt maps of the Russian Far East, Alaska, and the Canadian Cordillera, US Geological Survey, Open-File Report 98-136, CD-ROM, 1998.

Obolenskiy, A. A., Rodionov, S. M., Ariunbileg, S., Dejidmaa, G., Distanov, E. G., Dorjgotov, D., Gerel, O., Hwang, D. H., Sun, F., Gotovsuren, A., Letunov, S. N., Li, Xujun, Nokleberg, W. J., Ogasawara, M., Seminsky, Z. V., Smelov, A. P., Sotnikov, V. I., Spiridonov, A. A., Zorina, L. V., and Yan, H.: Mineral deposit models for Northeast Asia, in: Preliminary Publications Book 2 from Project on Mineral Resources, Metallogenesis, and Tectonics of Northeast Asia, edited by: Nokleberg, W. J., Miller, R. J., Naumova, V. V., et al., US Geological Survey, Open-File Report 03-203, CD-ROM, 44 pp., 2003a.

Obolenskiy, A. A. Rodionov, S. M. Dejidmaa, G., Gerel, O., Hwang, D. H., Miller, R. J., Nokleberg, W. J., Ogasawara, M., Smelov, A. P., Yan, H., and Seminskiy, Z. V.: Metallogenic belt and mineral deposit maps for Northeast Asia, US Geological Survey, Open-File Report 2004-1252, CD-ROM, 1 sheet, scale 1:7,500,000, 3 sheets, scale 1:5000000, explanatory text, 442 pp., 2004.

Obolenskiy, A. A., Rodionov, S. M., Dejidmaa, G., Gerel, O., Hwang, D. H., Miller, R. J., Nokleberg, W. J., Ogasawara, M., Smelov, A. P., Yan, H., and Seminskiy, Z. V., with compilations on specific regions by Ariunbileg, S., Biryul'kin, G. B., Byamba, J., Davydov. Y. V., Distanov, E. G., Dorjgotov, D., Gamyanin, 
G. N., Fridovskiy, V. Yu., Goryachev, N. A., Gotovsuren, A., Khanchuk, A. I., Kochnev, A. P., Kostin, A. V., Kuzmin, M. I., Letunov, S. A., Li, J., Li, X., Malceva, G. D., Melnikov, V. D., Nikitin, V. M., Parfenov, L. M., Popov, N. V., Prokopiev, A. V., Ratkin, V. V., Shpikerman, V. I., Sotnikov, V. I., Spiridonov, A. V., Stogniy, V. V., Sudo, S., Sun, F., Sun, J., Sun, W., Supletsov, V. M., Timofeev, V. F., Tyan, O. A., Vetluzhskikh, V. G., Waikta, K., Xi, A., Yakovlev, Y. V., Zhizhin, V. I.,. Zinchuk, N. N., and Zorina, L. M.: Preliminary metallogenic belt and mineral deposit location maps for Northeast Asia, US Geological Survey, Open-File Report 03-203, 1 sheet, scale 1:7500 000, 3 sheets, scale 1:15000 000, explanatory text, 143 pp., 2003b.

Parfenov, L. M., Khanchuk, A. I., Badarch, G., Berzin, N. A., Hwang, D. H., Miller, R. J., Naumova, V. V., Nokleberg, W. J., Ogasawara, M., Prokopiev, A. V., and Yan, H.: Generalized Northeast Asia geodynamics map, 2004, in: Digital files for Northeast Asia Geodynamics, Mineral Deposit Location, and Metallogenic Belt Maps, Stratigraphic Columns, Descriptions of Map Units, and Descriptions of Metallogenic Belts, edited by: Nokleberg, W. J., Badarch, G., Berzin, N. A., Diggles, M. F., Hwang, D. H., Khanchuk, A. I., Miller, R. J. Naumova, V. V., Obolenskiy, A. A., Ogasawara, M., Parfenov, L. M., Prokopiev, A. V., Rodionov, S. M., and Hongquan, Y., US Geological Survey, Open-File Report 2004-1252, CD-ROM, scale 1:15 000 000, 2004a.

Parfenov, L. M., Khanchuk, A. I., Badarch, G., Berzin, N. A., Miller, R. J., Naumova, V. V., Nokleberg, W. J., Ogasawara, M., Prokopiev, A. V., and Yan, H.: Descriptions of overlap assemblages and tectono-stratigraphic terranes, definitions, and methods for compilation for Northeast Asia geodynamics map, US Geological Survey, Open-File Report 2004-1252, CD-ROM, explanatory text, 167 pp., 2004b.

Parfenov, L. M., Khanchuk, A. I., Badarch, G., Miller, R. J., Naumova, V. V., Nokleberg, W. J., Ogasawara, M., Prokopiev, A. V., and Yan, H., with contributions on specific regions by: Belichenko, V., Berzin, N. A., Bulgatov, A. N., Byamba, J., Deikunenko, A. V., Dong, Y., Dril, S. I., Gordienko, I. V., Hwang, D. H., Kim, B. I., Korago, E. A., Kos'ko, M. K., Kuzmin, M. I., Orolmaa, D., Oxman, V. S., Popeko, L. I., Rudnev, S. N.,
Sklyarov, E. V., Smelov, A. P., Sudo, S., Suprunenko, O. I., Sun, F., Sun, J., Sun, W., Timofeev, V. F., Tret'yakov, F. F., Tomurtogoo, O., Vernikovsky, V. A., Vladimiro, A. G., Wakita, K., Ye, M., and Zedgenizov, A. N.: Preliminary Northeast Asia geodynamics map, US Geological Survey, Open-File Report 03-205, 2 sheets, scale 1:5000 000, 2003.

Parfenov, L. M., Nokleberg, W. J., and Khanchuk, A. I.: Principles of compilation and the main subdivisions of the legend of the geodynamic map of North and Central Asia, Russian Far East South, Korea and Japan, Geology of the Pacific Ocean, 17, 3-13, 1998 (in Russian).

Plafker, G. and Berg, H. D.: Overview of the geology and tectonic evolution of Alaska, in: The geology of Alaska, edited by: Plafker, G. and Berg, H.C., Geological Society of America, The Geology of North America, G1, 989-1021, 1994.

Remane, J.: Explanatory note to global stratigraphic chart, in: Circular of International Subcommission on Stratigraphic Classification (ISSC) of IUGS Commission on Stratigraphy, Appendix B: International Union of Geological Sciences (IUGS) Commission on Stratigraphy, 93, 11 pp., 1998.

Rodionov, S. M., Obolenskiy, A. A., Dejidmaa, G., Gerel, O., Hwang, D. H., Miller, R. J., Nokleberg, W. J., Ogasawara, M., Smelov, A. P., Yan, H., and Seminskiy, Z. V.: Descriptions of metallogenic belts, methodology, and definitions for Northeast Asia mineral deposit location and metallogenic belt maps, US Geological Survey, Open-File Report 2004-1252, CD-ROM, explanatory text, 442 pp., 2004.

Scotese, C. R., Nokleberg, W. J., Monger, J. W. H., Norton, I. O., Parfenov, L. M., Bundtzen, T. K., Dawson, K. M., Eremin, R. A., Frolov, Y. F., Fujita, Kazuya, Goryachev, N. A., Khanchuk, A. I., Pozdeev, A. I., Ratkin, V. V., Rodinov, S. M., Rozenblum, I. S., Shpikerman, V. I., Sidorov, A. A., and Stone, D. B.: Dynamic computer model for the metallogenesis and tectonics of the Circum-North Pacific, edited by: Nokleberg, W. J. and Diggles, M. F., US Geological Survey, Open-File Report 01-161, CD-ROM, 2001. 